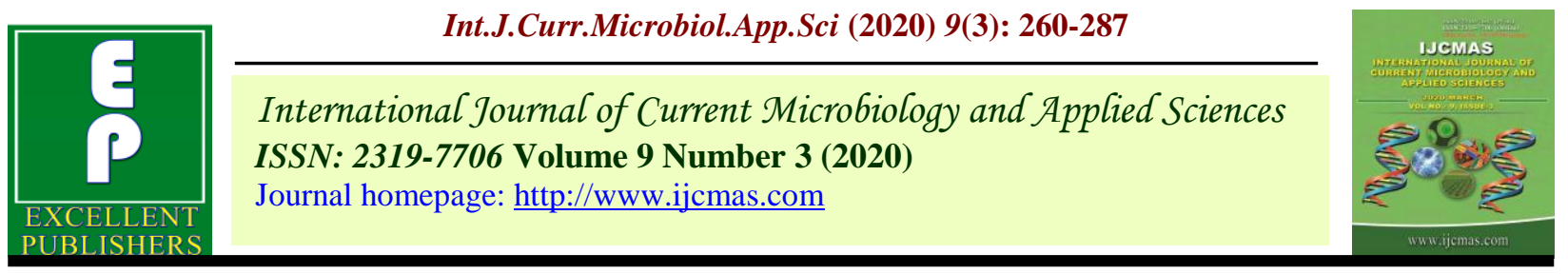

Original Research Article

https://doi.org/10.20546/ijcmas.2020.903.032

\title{
Optimization of Extraction Techniques for the Release of Intracellular L-Asparginase from Serratia marcescens MTCC 97 and its Characterization
}

\author{
Manisha Gautam*, Nisha and Wamik Azmi \\ Department of Biotechnology, Himachal Pradesh University, Summer Hill, \\ Shimla (H.P.) 171005, India \\ *Corresponding author
}

Keywords

L-asparaginase,

Serratia marcescens MTCC 97,

disintegration, sonication.

Article Info

Accepted:

05 February 2020

Available Online:

10 March 2020

\section{A B S T R A C T}

L-asparaginase acts as an efficient agent in curing certain sorts of lymphoma and leukemia by catalyzing the deamination of $\mathrm{L}$-asparagine to $\mathrm{L}$-aspartate and ammonia. Microorganisms are better source of L-asparginase, as their culturing, extraction and purification is more convenient than plants and other sources. As most of L-asparginases are intracellular in nature, so the selection of a suitable method for its release with maximum recovery was become more important. In present study, the resting cells of $S$. marcescens MTCC 97 were disintegrated by different enzymatic (lysozyme), chemical (alkali lysis, acetone powder, guanidine$\mathrm{HCl}$ and triton X-100) and physical (motor and pestle, vortex, bead beater and sonicator) methods. Among all methods explored, sonication was found best method with $0.05 \mathrm{U} / \mathrm{mg}$ specific activity and minimum loss of enzyme (8\%). Different reaction parameters were also optimized for the characterization of released L-asparginase. The extracted L-asparaginase showed maximum activity $(0.985 \mathrm{U} / \mathrm{ml})$ in $0.05 \mathrm{M}$ sodium phosphate buffer $(\mathrm{pH} 7.5)$ with L-asparagine $(8 \mathrm{mM})$ as substrate at $40^{\circ} \mathrm{C}$ incubation for $20 \mathrm{~min}$. Moreover, different metal ions, additives, chelating agents and protease inhibitors showed negative effects on Lasparaginase activity of resting cells and cell free extract obtained from $S$. marcescens MTCC 97.

\section{Introduction}

L-asparaginases are the enzymes that catalyse the hydrolysis of L-asparagine into Laspartate and ammonia. The L-asparaginases can be specific for L-asparagine, with negligible activity against glutamine (EC
3.5.1.1), or catalyze both asparagine and glutamine conversion (Sanches $\mathrm{M}$ et al., 2007). These enzymes act as important precursor in the treatment of Acute Lymphoblastic Leukemia in children due to antineoplastic activity (Umesh K et al., 2007). The malignant cells are differentiated from 
normal cells due to their nature in slow synthesis of L-asparagine, which causes starvation for this amino acid, while normal cells can produce this amino acid (Prakasham RS et al., 2009). The cancer cells have diminished expression of L-asparagine and mainly utilize the L-asparagine circulating in plasma pools (Manna S and Gram C, 1995; Swain AI et al., 1993).

The Escherichia coli and Erwinia chrysanthemi asparaginases are useful antileukaemic agents (Hill JM, 1967). Some asparaginases are also known to cause hemorrhage in the central nervous system, coagulation abnormalities, thrombosis and hypersensitivity reactions which are treatable upto $80 \%$ (Hourani R et al., 2008; Menon J et $a l .$, 2008). Clinical trials of L- asparaginase suggest this enzyme as a promising agent in treatment of neoplastic cell diseases in man with very low (1-2\%) risk of cerebral venous thrombosis (Oettgen HF et al., 1967; Erbetta A et al., 2008).

L-asparaginases are reported from various sources like plants, animals and microorganisms but the microorganisms are better source of L-asparaginase. It is easy to culture and extract the microbial sources and the purification of enzymes is also convenient from microorganism. A very active form of L-asparaginase was found in C. glutamicum under lysine producing fermentation conditions (Mesas JM et al., 1990). Most of L-asparaginases are intracellular in nature and need to be released from the cells for further applications. However, some extra cellular expression was also being exploited in recombinant DNA technology (Khushoo A et al., 2004). This enzyme was isolated from variety of sources such as Vibrio succinogenes, Proteus vulgaris and Pseudomonas fluorescens, which are are toxic to Lymphoblastic Leukaemia cells (Pritsa A and Kyriakidis DA, 2001). L-asparaginase conjugated with poly ethylene glycol approved in year 1994 in United States for the treatment of Acute Lymphocytic Leukemia with trade name Oncaspar®). In the biosynthesis of the aspartic amino acids, Lasparaginases play a very critical role. In addition the role of L-asparaginases in amino acid metabolism and their antitumor properties makes this enzyme of great therapeutic interest.

Number of methods for cell disintegration has been developed in order to release the intracellular products and enzymes from the cells. For the extraction of intracellular materials from the cells, it must be disintegrated either by physical (mechanical) or chemical methods but the selected method of disruption must ensure the protection of labile cell content from denaturation or thermal deactivation. There are some other methods involving genetic engineering of the microorganism to release enzymes to the external medium, but its scope is limited due to high production cost.

Although, in the past few years various intracellular enzymes have been produced by the industries like as: glucose oxidase for food preservation, penicillin acylase for antibiotic conversion and L-asparaginase for possible cancer therapy (Wang B et al., 2003). Chemical methods of cell disruption to release the cellular material may be advantageous as they employ use of acid, alkali, surfactants and solvents in some cases, but are generally avoided due to the limitation imposed by high cost at larger scale and damage due to acid/alkali, contamination of product with these chemicals, which further add more problems to downstream processing.

Mechanical/physical methods of cell disruption include both liquid (high pressure homogenizer) and solid shear (bead mill). The 
most commonly method used in large scale to small scale production of intracellular proteins from microorganisms is bead agitation or bead milling which involves the vigorously agitatation of harvested cells with beads in a closed chamber (Kula MR and Schutte H, 1987). Sonication, an another method of mechanical disruption had been previously employed for obtaining the cell free extract from Erwinia carotovora but there was biggest loss of enzyme occur during extraction (Krasotkina J et al., 2004). But still sonication has been found most effective method for release of intracellular Lasparaginase among chemical and other physical methods used for cell disruption in earlier reports (Singh RS, 2013).

Despite of many cell disintegration methods are available for laboratory scale, only limited number from these methods have been used for large scale applications. The high cost of products by manufacturer is due to necessity of harvesting the cells and extracts the required internal constituent (Kirsop $\mathrm{BH}$, 1981). In order to meet the requirements of Lasparaginases in therapeutics and the intracellular nature of this enzyme makes it necessary to search for a suitable cost effective method for its release from the microbial biomass. So, the present study was designed for the optimization of different extraction techniques for the release of intracellular L-asparginase from Serratia marcescens MTCC 97 and its characterization.

\section{Materials and Methods}

\section{Microorganism}

The culture of Serratia marcescens MTCC 97 used in this study was procured from the Department of Biotechnology, Himachal Pradesh University, Shimla. This culture was maintained in medium containing $(\%, \mathrm{w} / \mathrm{v})$ : malt extract 1.0, peptone $1.0, \mathrm{NaCl} 0.5$ and Lasparagine $0.1 \quad(\mathrm{pH} 7)$. After 24h of incubation, the culture was harvested by centrifugation at $10,000 \mathrm{rpm}$ for $15 \mathrm{~min}$ at $4^{\circ} \mathrm{C}$ and the resting cells were used for the release of the L-asparaginase.

\section{Estimation of cell mass}

The $24 \mathrm{~h}$ old culture broth was centrifuged at $10,000 \mathrm{rpm}$ for $15 \mathrm{~min}$ at $4^{\circ} \mathrm{C}$ and wet weight of cells was estimated. The wet cell pellet was placed in Oven at $80^{\circ} \mathrm{C}$ over night for drying. Dried cell pellets were cooled in desiccators and their weight were taken. The dried cell weight corresponding to their known amount of wet cell weight and their corresponding optical density was recorded and a standard graph was plotted between dry cell weight and $\mathrm{A}_{600}$.

\section{Assay of L-asparaginase activity}

Asparaginase activity was assayed according to the method of Meister A et al., (1955) and ammonia liberated was estimated by Fawett JK and Scott JE (2007) and the calorimetric Bradford assay was used for estimation of protein (Bradford MM, 1976). The Lasparaginase activity is expressed in terms of Unit (U).

\section{For whole cells}

The L-asparagine unit (U) has been defined as the $\mu$ moles of ammonia released / $\mathrm{mg}$ of dcw/ min under standard assay conditions.

\section{For cell free enzyme}

The L-asparaginase unit (U) has been defined as the $\mu$ moles of ammonia released $/ \mathrm{ml} / \mathrm{min}$ under standard assay conditions.

Specific activity - U/mg of proteins 


\section{For whole cells}

The L-asparagine unit (U) has been defined as the $\mu$ moles of ammonia released / $\mathrm{mg}$ of dcw/ min under standard assay conditions.

\section{For cell free enzyme}

The L-asparagine unit (U) has been defined as the $\mu$ moles of ammonia released $/ \mathrm{ml} / \mathrm{min}$ under standard assay conditions.

Specific activity - U/mg of proteins

\section{Procedure for enzyme assay}

Cell suspensions $(50 \mu \mathrm{l})$ of known $\mathrm{A}_{600}$ (25; equivalent to $10.75 \mathrm{mg} / \mathrm{ml} \mathrm{dcw}$ ) cells were taken in test tubes and $1.45 \mathrm{ml}$ of buffer was added to make the volume to $1.5 \mathrm{ml}$. The reaction is started by adding $0.5 \mathrm{ml}$ of $10 \mathrm{mM}$ substrate (L-asparagine) and the reaction mixtures were incubated at $45^{\circ} \mathrm{C}$ for $20 \mathrm{~min}$. The reaction is stopped by adding $0.5 \mathrm{ml}$ of trichloroacetic acid (15\%, w/v). In control tubes, $50 \mu \mathrm{l}$ cell suspensions were added after the addition of trichloroacetic acid. One $\mathrm{ml}$ reaction mixture was withdrawn from each tube (test and control) and released ammonia was measured. For the estimation of released enzyme, $50 \mu \mathrm{l}$ cell free extract was added in test and control. Rests of the conditions were similar to the assay procedure with resting cells.

Disintegration of resting cells of $S$. marcescens MTCC 97 for the release of $L$ asparaginase

The intracellular nature of the L-asparaginase in S. marcescens MTCC 97, Make mandatory to disintegrate the cells to release the Lasparaginase enzyme. Various enzymatic, chemical and physical methods were used for extraction of L-asparaginase from fresh biomass. The resting cells of $S$. marcescens
MTCC 97 were suspended in $0.05 \mathrm{M}$ sodium phosphate buffer (pH 7.5) with a cell concentration of $10.75 \mathrm{mg} / \mathrm{ml}$ after washing twice with the same buffer. After the release of L-asparaginase from the resting cells, calculations were made by using following formulas:

Recovery $(\%) \quad \begin{gathered}\text { Amount of released enzyme } \\ \text { Maximum enzyme activity }\end{gathered}$

Maximum enzyme activity (Amount of released enzyme + Amount of unreleased enzyme)

Loss $(\%)=$ - Maximum enzyme activity

Enzymatic method

Lysozyme treatment (Schutte $H$ and Kula MR, 1993)

In this method, cell pellet obtained from 100 $\mathrm{ml}$ of culture broth was suspended in $2 \mathrm{ml}$ of solution A (Glucose: 50mM, EDTA: $10 \mathrm{mM}$, Tris buffer: $25 \mathrm{mM}, \mathrm{pH} 8$ ) and $0.5 \mathrm{ml}$ of solution B (Lysozyme: $50 \mathrm{mg} / \mathrm{ml}$, Dissolved in solution A). Mixing was done by vertexing and mixture was incubated in ice for $10 \mathrm{~min}$. To the reaction contents $0.5 \mathrm{ml}$ of solution $\mathrm{C}$ (NaOH: $0.2 \mathrm{M}$ w/v, SDS:1\% w/v) was added, mixed and placed again in ice. The cell slurry was centrifuged at $10,000 \mathrm{rpm}$ for $10 \mathrm{~min}$ at $4^{\circ} \mathrm{C}$. The L-asparaginase activity was measured in the supernatant as well as in cell debris/unlysed cells.

\section{Chemical methods}

\section{Alkali lysis (Birnboim HC and Dolt J, 1979)}

Cell pellet obtained from $100 \mathrm{ml}$ of culture broth was suspended in $1 \mathrm{ml}$ of solution A (Glucose: 50mM, EDTA: 10mM, Tris buffer: $25 \mathrm{mM} \mathrm{pH} 8)$ and $2 \mathrm{ml}$ of solution $\mathrm{B}(\mathrm{NaOH}$ : 
$0.2 \mathrm{M} \mathrm{w} / \mathrm{v}$, SDS: $1 \% \mathrm{w} / \mathrm{v})$. The reaction contents were mixed by inverting the tubes 5 6 times and stored in ice. Then $1.5 \mathrm{ml}$ of ice cold solution $\mathrm{C}$ (Potassium acetate: $60 \mathrm{ml} 5 \mathrm{M}$, Glacial acetic acid:11.5 ml, Water: $28.5 \mathrm{ml}$ ) was added and the tubes were vertexed for 10 min. The cell slurry was centrifuged at 10,000 rpm for $10 \mathrm{~min}$ at $4^{\circ} \mathrm{C}$. The L-asparaginase activity was measured in the supernatant as well as in cell debris/unlysed cells.

\section{Acetone powder method (Somerville HJ et} al., 1970)

Cell pellet obtained from $100 \mathrm{ml}$ of culture broth was suspended in $10 \mathrm{ml}$ of anhydrous acetone and placed in ice for $30 \mathrm{~min}$ at $10^{\circ} \mathrm{C}$. The reaction contents were mixed by vertexing. Cell slurry was centrifuged at $10,000 \mathrm{rpm}$ for $10 \mathrm{~min}$ at $4^{\circ} \mathrm{C}$.

Cell pellet was suspended in $10 \mathrm{mM}$ of sodium borate buffer $\left(\mathrm{pH} \mathrm{6.5)}\right.$ and incubated at $40^{\circ} \mathrm{C}$ for $10 \mathrm{~min}$. Cell content was again centrifuged at $10,000 \mathrm{rpm}$ for $10 \mathrm{~min}$ at $4^{\circ} \mathrm{C}$. The L-asparaginase activity was measured in the supernatant as well as in cell debris/unlysed cells.

Triton $\mathrm{X}-100$ and guanidine-HCl treatment for cell disruption (Helenius A and Simons K, 1975)

Cell pellet obtained from the culture broth was suspended in $10 \mathrm{ml}$ of phosphate buffer $0.05 \mathrm{M}, \mathrm{pH} 7.5$ (containing $10.75 \mathrm{mg} / \mathrm{ml} \mathrm{dcw}$ ) and $4 \mathrm{ml}$ of $2 \mathrm{M}$ Guanidine $\mathrm{HCl}$ was added to it. To this reaction mixture $0.24 \mathrm{ml}$ of Triton X-100 2\% (v/v) was added.

The reaction contents were mixed and incubated at room temperature for $15 \mathrm{~min}$. Cell slurry was centrifuged at $10,000 \mathrm{rpm}$ for $10 \mathrm{~min}$ at $4^{\circ} \mathrm{C}$. The L-asparaginase activity was measured in the supernatant as well as in cell debris/unlysed cells.

\section{Physical methods}

Disruption of cells by crushing with glass beads in pestle and mortar

Cell pellet obtained from the culture broth was suspended in $15 \mathrm{ml}$ of phosphate buffer

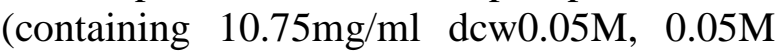
$\mathrm{pH}$ 7.5). The PMSF $(0.5 \mathrm{mM} 0.1 \mathrm{ml})$ was added to cell slurry $\left(A_{600}=25\right)$. The cell slurry was crushed continuously with $15 \mathrm{ml}$ glass beads for 25 min with the help of mortar and pestle in ice chamber to avoid loss of activity due to heat generation during crushing. The crushed mixture was centrifuged at $10,000 \mathrm{rpm}$ for $10 \mathrm{~min}$ at $4^{\circ} \mathrm{C}$. The L-asparaginase activity was measured in the supernatant as well as in cell debris/unlysed cells.

\section{Disruption of cells by Bead Beater (Kula MR and Schutte H, 1987; Chisti Y and Moo-Young M, 1991)}

Cell pellet obtained from $300 \mathrm{ml}$ of culture broth was suspended in $40 \mathrm{ml}$ of phosphate buffer (containing $10.75 \mathrm{mg} / \mathrm{ml} \mathrm{dcw}$ ). The cell slurry $\left(\mathrm{A}_{600}=25\right)$ was disrupted by the use of Bead Beater ${ }^{\mathrm{TM}}$ for 36 min. Beads of different diameter (Zirconium $0.5 \mathrm{~mm}$, Glass beads $0.5 \mathrm{~mm}$ and $0.1 \mathrm{~mm}$ ) were used for the disruption of cells with a pulse of 1 min on and $2 \mathrm{~min}$ off to avoid heat generation. The assembly containing cell slurry was ice jacketed during the cell disruption cycle. The sample was withdrawn after every 1 min for assay of L-asparaginase activity in supernatant and cell debris/unlysed cells.

Disruption of cells by Sonication (Singh RS, 2013)

Cell pellet obtained from the culture broth was suspended in $40 \mathrm{ml}$ of phosphate buffer (containing $10.75 \mathrm{mg} / \mathrm{ml} \mathrm{dcw}$ ). The cell slurry $\left(\mathrm{A}_{600}=25\right)$ was disrupted by the use of 
sonicatior for $22 \mathrm{~min}$ with a pulse of $60 \mathrm{sec}$ (60 sec on and $60 \mathrm{sec}$ off) at $250 \mathrm{~W}$ by keeping the probe (diameter 1 inch) above the bottom of vial. The vial was ice jacketed during the sonication. The samples were withdrawn after every 1 min for the assay of L-asparaginase activity in supernatant and cell debris/unlysed cells.

Optimization of parameters for the maximum release of $L$-asparaginase by sonication

\section{Number of pulse cycles}

The $40 \mathrm{ml}$ cell slurry $\left(\mathrm{A}_{600}=25\right)$ was disrupted with the sonicator for 22 min with a pulse of $60 \mathrm{sec}$ and at $39 \%$ amplitude. The sample was withdrawn after every $60 \mathrm{sec}$ and centrifuged at $10,000 \mathrm{rpm}$ for $10 \mathrm{~min}$ at $4^{\circ} \mathrm{C}$. The L-asparaginase activity was measured in the supernatant and pellets both. The cycle which showed the highest activity was selected and used for further studies.

\section{Cell concentration}

The cell slurry $(40 \mathrm{ml})$ of different cell concentration $\quad(2.15 \mathrm{mg} / \mathrm{ml}, \quad 4.3 \mathrm{mg} / \mathrm{ml}$, $6.45 \mathrm{mg} / \mathrm{ml}, \quad 8.6 \mathrm{mg} / \mathrm{ml}, \quad 10.75 \mathrm{mg} / \mathrm{ml}$, $10.75 \mathrm{mg} / \mathrm{ml}, 12.9 \mathrm{mg} / \mathrm{ml}$ and $15.05 \mathrm{mg} / \mathrm{ml}$ ) were lysed by the sonicator for 9 cycles. The released L-asparaginase activity was measured for each cell concentration in cell free extract and cell debris/unlysed cells. The cell concentration which showed the maximum enzyme activity was selected as the optimum concentration of cells to be used for further studies.

\section{Cell volume}

Different cell volumes $(20 \mathrm{ml}, 30 \mathrm{ml}, 40 \mathrm{ml}$ and $50 \mathrm{ml}$ ) resting cell of selected concentration $(10.75 \mathrm{mg} / \mathrm{ml})$ was used for cell disintegration. For each cell volume the released L-asparaginase activity was measured in cell free extract and cell debris/unlysed cells.

\section{Amplitude of sonication}

The cell slurry $(40 \mathrm{ml})$ of cell concentration $10.75 \mathrm{mg} / \mathrm{ml}$ was lysed in sonicator for 9 cycles at different amplitudes $(30 \%, 35 \%$ and $39 \%$ ). The L-asparaginase activity was measured in the cell free extract and cell debris/unlysed cells.

\section{Characterization of L-asparaginase released from the resting cells of $S$. marcescens MTCC 97}

The reaction conditions were optimized for the assay of L-asparaginase activity in cell free extract obtained from $S$. marcescens MTCC 97 and compared with the Lasparaginase of the resting cells of $S$. marcescens MTCC 97.

\section{Selection of buffer and optimization of $\mathrm{pH}$}

The optimum $\mathrm{pH}$ of released L-asparaginase enzyme was evaluated by measuring the Lasparaginase activity in different buffers of $0.1 \mathrm{M}$ concentration. The buffers used were; Acetate buffer ( $\mathrm{pH}$ 4.0-6.0), Sodium phosphate buffer ( $\mathrm{pH}$ 6.0-8.0), Potassium phosphate buffer ( $\mathrm{pH} 7.0-8.5)$, Citrate buffer (pH 4.5-6.5), Glycine NaOH buffer ( $\mathrm{pH} 9.0-$ 10.0), Carbonate-bicarbonate buffer $(\mathrm{pH} 9.5-$ 10.5), Citrate phosphate buffer $(\mathrm{pH} 2.5-7.0)$ were used to perform the assay. The same set of experiment was also performed with resting cells of $S$. marcescens MTCC 97.

\section{Optimization of buffer molarity}

To study the effect of concentration of buffer on released L-asparaginase, Sodium phosphate buffer $(\mathrm{pH}$ 7.5) of different concentration $(0.01 \mathrm{M}-0.07 \mathrm{M})$ was used for 
the assay of L-asparaginase activity in cell free extract and resting cells.

\section{Optimization of reaction temperature}

The optimum temperature of the Lasparaginase from $S$. marcescens MTCC 97 was obtained by measuring the Lasparaginase activity in cell free extract and resting cells at different incubation temperature $\left(30^{\circ} \mathrm{C}, 35^{\circ} \mathrm{C}, 40^{\circ} \mathrm{C}, 45^{\circ} \mathrm{C}, 50^{\circ} \mathrm{C}\right.$ and $55^{\circ} \mathrm{C}$ ) with L-asparagine as substrate and $0.05 \mathrm{M}$ sodium phosphate buffer ( $\mathrm{pH} 7.5$ ).

\section{Effect of incubation time}

Optimum reaction time was evaluated by incubating the reaction contents for different time intervals $(10,15,20,25,30$ and $35 \mathrm{~min})$ and optimum $\mathrm{pH}$ and temperature. The Lasparaginase activity was measured in resting cells and cell free extract obtained from $S$. marcescens MTCC 97.

\section{Substrate specificity}

To find out the substrate specificity of Lasparaginase of $S$. marcescens MTCC 97, the activity of enzyme was determined at different substrate like L-asparagine, Lglutamine, D-asparagine and DL-asparagine at $10 \mathrm{mM}$ concentration. The experiment was performed with resting cells and cell free extract obtained from $S$. marcescens MTCC 97.

\section{Substrate concentration}

For the optimization of substrate concentration of released L-asparaginase and resting cells of $S$. marcescens MTCC 97, different substrate concentrations of Lasparagine $(2 \mathrm{mM}-14 \mathrm{mM})$ were used and assay was performed under optimized conditions.

\section{Role of metal ion}

The L-asparaginase activity was assayed in presence of $1 \mathrm{mM}$ concentration of metal ions, additives, inhibitors and chelating agents $\left(\mathrm{FeCl}_{3}, \mathrm{MgSO}_{4} \cdot 6 \mathrm{H}_{2} \mathrm{O}, \mathrm{ZnSO}_{4} .7 \mathrm{H}_{2} \mathrm{O}, \mathrm{COCl}_{2}\right.$, $\mathrm{CuSO}_{4} .5 \mathrm{H}_{2} \mathrm{O}, \quad \mathrm{NaCl}, \quad \mathrm{AgNO}_{3}, \quad \mathrm{BaCl}_{2}$, Dithiothreitol, Ethylene diamine tetra acetic acid, Phenyl methyl sulphonyl fluoride, $\mathrm{HgCl}_{2}, \quad \mathrm{CaCl}_{2} \cdot 2 \mathrm{H}_{2} \mathrm{O}$, Urea, Polyethylene glycol (PEG), $\mathrm{Pb}\left(\mathrm{NO}_{3}\right)_{2}, \mathrm{MnCl}_{2} \cdot \mathrm{H}_{2} \mathrm{O}$ and $\mathrm{KCl})$ under previously optimized conditions for cell free extract and resting cells of $S$. marcescens MTCC 97.

\section{Determination of $K_{\mathrm{m}}$ and $V_{\max }$ of released enzyme}

$K_{\mathrm{m}}$ and $V_{\max }$ values were determined by plotting a graph between $1 / \mathrm{V}$ and $1 / \mathrm{S}$ for resting cells and free extract obtained from $S$. marcescens MTCC 97.

\section{Stability profile of purified enzyme}

The Stability of enzyme was determined at three different temperatures $\left(4^{\circ} \mathrm{C}, 25^{\circ} \mathrm{C}\right.$, $30^{\circ} \mathrm{C}, 40^{\circ} \mathrm{C}$ and $50^{\circ} \mathrm{C}$ ). The enzymes (cell free extract and resting cells) were incubated at these temperatures and activity was measured at regular interval of $30 \mathrm{~min}$.

\section{Results and Discussion}

Optimization of cell disintegration methods for release of L-asparaginase from Serratia marcescens MTCC 97

The isolation of intracellular enzymes requires a suitable cell disruption method (enzymatic, chemical or physical) to release its contents into the surrounding medium (Chisti Y and Moo-Young M, 1991). The Lasparaginase from $S$. marcescens MTCC 97 is an intracellular enzyme and can only obtain by cell disruption. There are several methods 
of partial or selective disruption of membranes to solublise bound proteins including the use of chelating agents, adjustment of ionic strength, $\mathrm{pH}$, organic solvents and detergents (Somerville HJ et al., 1970; Helenius A and Simons K, 1975; Marchesi SL et al., 1970; Schnebli HP and Abrams A, 1970). The resting cells of known $\mathrm{A}_{600}$ (25; equivalent to $\left.10.75 \mathrm{mg} / \mathrm{ml} \mathrm{dcw}\right)$ obtained from S. marcescens MTCC 97 were disintegrated by different enzymatic (lysozyme), chemical (alkali lysis, acetone powder, Triton X-100 and Guanidine-HCl) and physical (motar and pestle, vortex, Bead Beater and Sonicator) methods.

\section{Enzymatic method}

In enzymatic methods, the amount of enzyme released was found $7.13 \mathrm{U}$ (Table 1). However, $4.04 \mathrm{mg} / \mathrm{ml}$ protein was found in the supernatant with $0.073 \mathrm{U} / \mathrm{mg}$ specific activity. Even after cell lysis, 5.96 U the enzyme activity was remaining in the unlysed cells. Recovery of L-asparaginase was found to be $42 \%$ and almost $13 \%$ loss in the enzyme activity was observed. Cell lysis of Gram's negative bacteria was aided by the addition of EDTA to chelate the divalent cations (Schutte $\mathrm{H}$ and Kula MR, 1993) and lysozyme was used to cleave $\beta$ (1-4) glycocidic linkage of bacterial cell wall (Bucke C, 1983). However, the process was very costly at large scale economics points of view.

\section{Chemical methods}

\section{Alkali lysis method}

Less quantity of L-asparaginase release $(0.48$ $\mathrm{U})$ with specific activity of $0.030 \mathrm{U} / \mathrm{mg}$ of protein was observed when the cells of $S$. marcescens MTCC 97 were subjected to alkali lysis (Table 2). However, the amount of protein released was found to be $(3.55 \mathrm{mg} / \mathrm{ml})$. The decrease in enzyme activity might be due to the denaturation of enzyme by SDS. The Lasparaginase recovery was found to be $6 \%$ with a loss of $38 \%$ after the cell lysis.

\section{Acetone powder}

The acetone powder was prepared to release the L-asparaginase resting cells of $S$. marcescens MTCC 97. Overall $6.58 \mathrm{mg} / \mathrm{ml}$ protein was released in the supernatant with enzyme activity of $1.37 \mathrm{U}$. The specific activity was found to be $0.021 \mathrm{U} / \mathrm{mg}$ of protein (Table 3).

\section{Triton X-100 and Guanidine-HCl}

On the treatment of resting cells of $S$. marcescens MTCC 97 with Triton X-100 and Guanidine- $\mathrm{HCl}, \quad 0.26 \mathrm{U} / \mathrm{ml}$ L-asparaginase was released in supernatant with $2.47 \mathrm{mg} / \mathrm{ml}$ yield of protein (Table 4). The specific activity of enzyme was $0.007 \mathrm{U} / \mathrm{mg}$ of protein. The overall loss in the enzyme activity was $12 \%$ with $3 \%$ recovery of enzyme. Therefore, this method was not found to be suitable for lysis as the specific activity of enzyme was very less and recovery was also low. Among the three chemical methods used for the disruption of the resting cells of $S$. marcescens MTCC 97, the treatment of the cells with Triton X-100 and Gaunidine- $\mathrm{HCl}$ gave maximum yield $(0.26 \mathrm{U}$ of released enzyme) with the release of $2.47 \mathrm{mg} / \mathrm{ml}$ of protein and specific activity of the enzyme was found to be $0.007 \mathrm{U} / \mathrm{mg}$ of protein. Furthermore, with very less recovery (3\%), this method was found to be unsuitable for the release of L-asparaginase from the resting cells of S. marcescens MTCC 97. Resting cells of $S$. marcescens MTCC 97 were also lysed by acetone powder treatment method with $17 \%$ recovery of L-asparaginase. Moreover, during this procedure 30\% loss in L-asparaginase was also recorded. However acetone treatment was used to increase the permeability of cell wall of E. carotovora and 
enzyme recovery in cell free extract was reported to 57\% (Lee SM et al., 1989).

\section{Physical methods}

\section{Disintegration of cells in motar and pestle}

In supernatant $3.09 \mathrm{U}$ enzyme activity and $6.62 \mathrm{mg} / \mathrm{ml}$ protein was obtained after the cell disruption in motor and pestle (Table 5). The specific activity of the released Lasparaginase was $0.031 \mathrm{U} / \mathrm{mg}$ of protein. The loss in enzyme activity was $8 \%$ with overall recovery of $26 \%$ of L-asparaginase.

\section{Disintegration of cells by vortexing with glass beads}

Disintegration of the resting cells of $S$. marcescens MTCC 97 was also tried by vortexing the cell slurry with glass beads $(0.5 \mathrm{~mm})$. The amount of L-asparaginase released was found to be $3.45 \mathrm{U}$ and the protein obtained in supernatant was $6.26 \mathrm{mg} / \mathrm{ml}$ (Table 6). The specific activity of the supernatant was $0.043 \mathrm{U} / \mathrm{mg}$ of protein. The L-asparaginase activity in the cells before disruption was $1.095 \mathrm{U}$ and cells retained $0.072 \mathrm{U}$ L-asparaginase after the cell disruption. The overall loss in enzyme activity was $5 \%$ with a recovery of $29 \%$.

\section{Disintegration of cells by Bead Beater using Zirconium beads $(0.5 \mathrm{~mm})$}

The cell slurry $(40 \mathrm{ml})$ of $S$. marcescens MTCC 97 was disintegrated in a Bead Beater by using Zirconium beads of $0.5 \mathrm{~mm}$ diameter. The activity in supernatant was $9.48 \mathrm{U}$ with $7.20 \mathrm{mg} / \mathrm{ml}$ of released protein (Table 7 ). The specific activity was found to be $0.029 \mathrm{U} / \mathrm{mg}$ of protein. Activity in cells before disruption was $33.54 \mathrm{U}$ and cell retained $2.58 \mathrm{U}$ of enzyme after the cell disruption. The overall recovery was $28 \%$ with $64 \%$ loss.
Disintegration of cells by glass beads (0.5mm)

The $40 \mathrm{ml}$ resting cells suspension of $S$. marcescens MTCC 97 was disrupted by using glass beads of $0.5 \mathrm{~mm}$ diameter in Bead Beater. The released L-asparaginase activity and protein was found to be $8.29 \mathrm{U}$ and $13.28 \mathrm{mg} / \mathrm{ml}$, respectively (Table 8 ). The specific activity of released enzyme was $0.017 \mathrm{U} / \mathrm{mg}$ of protein. The overall recovery of L-asparaginase was $24 \%$ with $64 \%$ loss in the enzyme activity.

Disintegration of cells by glass beads (0.1mm)

The cell slurry $(40 \mathrm{ml})$ of $S$. marcescens MTCC 97 was disrupted by using glass beads of $0.1 \mathrm{~mm}$ diameter. The L-asparaginase release was found to be $19.20 \mathrm{U}$ with $16.67 \mathrm{mg} / \mathrm{ml}$ of protein (Table 9). The specific activity of cell free extract was $0.032 \mathrm{U} / \mathrm{mg}$ of protein. The recovery of L-asparaginase was better $(50 \%)$ but the loss in the enzyme activity was also very significant (48\%).

\section{Disintegration of cells by sonication}

The disintegration of resting cells of $S$. marcescens MTCC 97 was carried out by sonication. After $9^{\text {th }}$ cycle of sonication, 27.0 $\mathrm{U}$ of L-asparaginase and $19.06 \mathrm{mg} / \mathrm{ml}$ of protein were released in the supernatant (Table 10). The specific activity of released L-asparaginase was found to be $0.05 \mathrm{U} / \mathrm{mg}$ proteins. The recovery of L-asparaginase was $68 \%$ with a little loss $(8 \%)$ in of enzyme activity.

Optimization of various parameters for the release of L-asparaginase from $S$. marcescens MTCC 97 cells by Sonication

As the recovery of L-asparaginase was maximum with sonication method with very 
less loss of enzyme activity, the different parameters of sonication like pulse rate, cell volume and cell concentration for the maximum release of the enzyme were also optimized.

\section{Optimization of pulse rate}

The $40 \mathrm{ml}$ cell slurry of $S$. marcescens MTCC 97 was sonicated for 12 cycles of a pulse of $60 \mathrm{sec}$. The maximum enzyme activity $(0.871$ $\mathrm{U} / \mathrm{ml})$ and specific activity $(0.047 \mathrm{U} / \mathrm{mg}$ protein) was found at the $9^{\text {th }}$ cycle of sonication (Table 11). The specific activity of enzyme decreased after $9^{\text {th }}$ cycle possibly due to the thermal denaturation. These results suggest that the 9 on/off cycles were optimum for the maximum release of L-asparaginase from the resting cells of $S$. marcescens MTCC 97.

\section{Optimization of cell concentration}

The $40 \mathrm{ml}$ cell slurry of $S$. marcescens MTCC 97 containing varying amount of resting cells were sonicated for the release of Lasparaginase (Table 4.12 A, B, C, D, E, F and $\mathrm{G})$. The amount of enzyme released was decreased beyond the cell concentration of $10.75 \mathrm{mg} / \mathrm{ml}$. The maximum protein $(19.05 \mathrm{mg} / \mathrm{ml})$ was released at the cell concentration of $10.75 \mathrm{mg} / \mathrm{ml}$ with maximum recovery of $68 \%$. Therefore, $10.75 \mathrm{mg} / \mathrm{ml}$ resting cells were further used for the release of L-asparaginase by sonication.

\section{Optimization of cell volume}

Different volumes (20-50 ml) of cell slurry of S. marcescens MTCC 97 containing $10.75 \mathrm{mg} / \mathrm{ml}$ resting cells were lysed for 9 on/off cycles of sonication (Table $13 \mathrm{~A}, \mathrm{~B}, \mathrm{C}$ and $\mathrm{D})$. The maximum enzyme (32.0 U) was released when $40 \mathrm{ml}$ of cell slurry was used. There was a decrease in activity when a higher volume of cell slurry was used.

\section{Optimization of amplitude}

The $40 \mathrm{ml}$ cell slurry (containing $10.75 \mathrm{mg} / \mathrm{ml}$ cells) was sonicated at different amplitudes (30, 35 and 39\%) for 9 on/off cycles (Table $14 \mathrm{~A}, \mathrm{~B}$ and $\mathrm{C})$. It is important to mention that the maximum amplitude of sonicator should not exceed $39 \%$. The most efficient amplitude was found to be $39 \%$. Below this amplitude the lysis was not very effective as the activity in pellet after lysis was found to be very high.

Characterization of L-asparaginase released from the resting cells of $S$. marcescens MTCC 97

The reaction conditions were optimized for the assay of L-asparaginase activity in resting cells as well as cell free extract obtained from S. marcescens MTCC 97.

\section{Selection of buffer and optimization of $\mathrm{pH}$}

For the selection of buffer of optimum $\mathrm{pH}, 7$ buffers of $0.1 \mathrm{M}$ concentration having different $\mathrm{pH}$ range (4-10.5) were tested. The maximum L-asparaginase activity was found with $0.1 \mathrm{M}$ sodium phosphate buffer ( $\mathrm{pH} 7.5)$ in resting cells $(0.116 \mathrm{U} / \mathrm{mg} \mathrm{dcw})$ and same buffer was found to be most suitable for cell free extract of $S$. marcescens MTCC 97 with maximum L-asparaginase activity $0.558 \mathrm{U} / \mathrm{ml}$ (Table 16). This data suggest that the released enzyme had optimum $\mathrm{pH}$ similar to that of resting cell preparations. The activity falls in both cases (resting cells as well as in cell free extract) as the $\mathrm{pH}$ was altered from the optimum. The reason behind this may be that enzyme was unable to retain its activity at high or low $\mathrm{pH}$ due to the fact that active site losses its affinity towards substrate at these $\mathrm{pH}$. The reaction conditions of L-asparaginase produced by $S$. marcescens MTCC 97 were optimized to find out the most favourable conditions for enzyme to exhibit its maximum activity. Various buffers of $\mathrm{pH}$ range (4-10.5) 
were used to perform enzyme assay. The maximum L-asparaginase activity was obtained with $0.05 \mathrm{M}$ sodium phosphate buffer ( $\mathrm{pH} 7.5$ ) in resting cells as well as for cell free extract of $S$. marcescens MTCC 97. The enzyme from Erwinia carotovora has optimum $\mathrm{pH}$ 8.0, which was completely different from the whole cell optimum $\mathrm{pH}$, which are 7.3 (Maladkar and George, 1993). However, the commercial preparation of $\mathrm{L}$ asparaginase (Elspar) was found to be stable at wide $\mathrm{pH}$ range of 4.5-11.5 (Stecher AL et al., 1999).

\section{Optimization of buffer molarity}

Different concentrations (10-70mM) of sodium phosphate buffer ( $\mathrm{pH} 7.5)$ were used to select the optimum molarity of the buffer. Maximum L-asparaginase activity was obtained with $50 \mathrm{mM}$ concentration of sodium phosphate buffer ( $\mathrm{pH} 7.5)$ in resting cells as well as in cell free extract of $S$. marcescens MTCC 97. In resting cells and cell free extract the L-asparaginase activity was found to be $0.121 \mathrm{U} / \mathrm{mg} \mathrm{dcw}$ and $0.815 \mathrm{U} / \mathrm{ml}$, respectively (Fig. 1).

\section{Optimization of reaction temperature}

The reaction mixture containing cell free extract and resting cells of $S$. marcescens MTCC 97 were separately incubated at different temperature $\left(30^{\circ} \mathrm{C}-55^{\circ} \mathrm{C}\right)$. Maximum L-asparaginase activity in resting cells $(0.146$ $\mathrm{U} / \mathrm{mg} \mathrm{dcw})$ and in cell free extract $(0.754$ $\mathrm{U} / \mathrm{ml}$ ) activity was observed at $40^{\circ} \mathrm{C}$ (Fig. 2). However, with further increase in incubation temperature, L-asparaginase activity decreased in both cases. The optimum reaction temperature was found to be $40^{\circ} \mathrm{C}$ in resting cells and in cell free extract of $S$. marcescens MTCC 97 which coincide with $C$. glutamicum having the same optimum reaction temperature (Mesas JM et al., 1990).

\section{Effect of incubation time}

Optimum reaction time was evaluated by incubating the reaction contents for different time intervals $(10,15,20,25,30$ and $35 \mathrm{~min})$ at optimum $\mathrm{pH}$ and temperature. The Lasparaginase activity in cell free extract of from S. marcescens MTCC 97 obtained was $0.760 \mathrm{U} / \mathrm{ml}$ after $20 \mathrm{~min}$ of incubation (Fig. 3). Similar incubation time was found to be optimum for the maximum $(0.140 \mathrm{U} / \mathrm{mg} \mathrm{dcw})$ L- asparaginase activity. Enzyme activity started decreasing when incubation time was increased beyond $20 \mathrm{~min}$ in both the cases.

\section{Substrate specificity}

To find out the most specific substrate for the L-asparaginase of S. marcescens MTCC 97, the activity of enzyme was determined with different substrate (L-asparagine, Lglutamine, D-asparagine and DL-asparagine) at $10 \mathrm{mM}$ concentration. It was found that the L-asparagine was most suitable substrate for the L-asparaginase of S. marcescens MTCC 97. The resting cells and cell free extract exhibited $0.145 \mathrm{U} / \mathrm{mg} \mathrm{dcw}$ and $0.826 \mathrm{U} / \mathrm{ml}$ of L-asparaginase activity, respectively. Moreover, it also showed very little Dasparaginase activity and L-glutaminase activity (Fig. 4). The most favorable substrate for the L-asparaginase from $S$. marcescens MTCC 97 was L-asparagine but this enzyme showed very little activity towards substrate D-asparagine also. Moreover, this enzyme also exhibit significant L-glutaminase activity.

\section{Substrate concentration}

Different concentrations of L-asparagine (2mM-14mM) were used to obtain the optimum substrate concentration for the Lasparaginase of $S$. marcescens MTCC 97. The maximum L-asparaginase activity was found to be $0.154 \mathrm{U} / \mathrm{mg} \mathrm{dcw}$ with $10 \mathrm{mM}$ 
concentration of L-asparagine with resting cells (Fig. 5). However, for the cell free extract of $S$. marcescens MTCC 97, the maximum L-asparaginase activity was obtained at $8 \mathrm{mM}$ concentration of Lasparagine $(0.985 \mathrm{U} / \mathrm{ml})$. A sharp decrease in L-asparaginase activity was observed with further increase in L-asparagine concentration in both cases. These finding suggest the possibility of substrate inhibition at the higher concentration of L-asparagine.

\section{Role of metal ion}

The L-asparaginase activity was assayed in presence of $1 \mathrm{mM}$ concentration of metal ions, additives, inhibitors and chelating agents under optimized conditions for cell free extract and resting cells of $S$. marcescens MTCC 97. The metal ions $\mathrm{AgNO}_{3}$ and $\mathrm{HgCl}_{2}$ inhibited the L-asparaginase activity in resting cells as well as in cell free extract. A slight increase in enzyme activity was observed by the use of $\mathrm{BaCl}_{2}, \mathrm{CaCl}_{2} \cdot 2 \mathrm{H}_{2} \mathrm{O}$, Ethylene diamine tetra acetic acid (EDTA) and Phenyl methyl sulphonyl fluoride in resting cells and $\mathrm{MnCl}_{2} \cdot \mathrm{H}_{2} \mathrm{O}$ in cell free extract. On the basis of insignificant effect of these metal ions on L-asparaginase activity, it can be suggested that the L-asparaginase of $S$. marcescens MTCC 97 is not a metalloprotien (Fig. 6).

Presence of metal ions does not affect Lasparaginase production indicates that it is not a metalloprotein or does not require co-factor. Presence of chelating agents (EDTA) and compounds having thiol protecting groups (glutathione, dithiothretol, 2-mercaptoethalnol etc) markedly enhance the L-asparaginase activity of Cylindrocarpon obtusisporum MB10(Raha SK et al., 1990).

\section{Determination of $K_{\mathrm{m}}$ and $V_{\max }$ of enzyme}

$K_{\mathrm{m}}$ and $V_{\max }$ values of L-asparaginase were determined by plotting a graph between $1 / \mathrm{V}$ and $1 / \mathrm{S}$ for cell free extract and resting cells of $S$. marcescens MTCC 97. The values of $V_{\max }$ and $K_{\mathrm{m}}$ was found to be $1.65 \mathrm{U}$ and $5.6 \mathrm{x}$ $10^{-3} \mathrm{M}$, respectively for the cell free extract of S. marcescens MTCC 97 (Fig. 4.7). However, the $V_{\max }$ and $K_{\mathrm{m}}$ were $0.19 \mathrm{U}$ and $1.85 \times 10^{-3}$ M, respectively for the resting cells of $S$. marcescens MTCC 97 (Fig. 8). The high $K_{\mathrm{m}}$ value of cell free extract suggests that the released L-asparagine has less affinity for Lasparagine than the resting cells of $S$. marcescens MTCC 97.

The $K_{\mathrm{m}}$ values obtained for L-asparaginase in resting cells and cell free extract of $S$. marcescens MTCC 97 were $1.85 \times 10^{-3} \mathrm{M}$ and $5.6 \times 10^{-3} \mathrm{M}$, respectively. The $K_{\mathrm{m}}$ value of a recombinant L-asparaginase ECAR LANS was found to be $1.6 \times 10^{-2} \mu \mathrm{M}$ [16]. The minimum $K_{\mathrm{m}}$ value for L-asparaginase so far reported in Pseudomonas 7A $\left(4.4 \times 10^{-6} \mathrm{M}\right)$ by Rozalska M and Mikucki J, 1992).

\section{Stability profile of L-asparaginase}

The Stability of L-asparaginase was determined at five different incubation temperatures $\left(4^{\circ} \mathrm{C}, 25^{\circ} \mathrm{C}, 30^{\circ} \mathrm{C}, 40^{\circ} \mathrm{C}\right.$ and $\left.50^{\circ} \mathrm{C}\right)$. The L-asparaginase from $S$. marcescens MTCC 97 (cell free extract and resting cells) were incubated at these temperatures and activity was determined at regular interval of $30 \mathrm{~min}$. The resting cells and cell free extract of $S$. marcescens MTCC 97 was found to be most stable at $4^{\circ} \mathrm{C}$. The half-life of L-asparaginase obtained at $25^{\circ} \mathrm{C}$ and $30^{\circ} \mathrm{C}$ was $240 \mathrm{~min}$ for the resting cells as well as the cell free extract of $S$. marcescens MTCC 97 (Fig. 4.9 and Fig. 10). When the temperature was increased to $40^{\circ} \mathrm{C}$, the halflife of L-asparaginase decreased to $210 \mathrm{~min}$ in both the cases. Moreover, at higher incubation temperature $\left(50^{\circ} \mathrm{C}\right)$ the half-life of Lasparaginase in cell free extract and in resting cells was found to be 180 and $90 \mathrm{~min}$, respectively. 
Table.1 Lysis of the resting cells of S. marcescens MTCC 97 cells by lysozyme

\begin{tabular}{|c|c|c|c|c|c|c|}
\hline \multirow{2}{*}{ Conditions } & \multicolumn{2}{|c|}{$\begin{array}{c}\text { Enzyme activity } \\
(\mathbf{U})\end{array}$} & $\begin{array}{c}\text { Released } \\
\text { protein } \\
(\mathbf{m g} / \mathbf{m l})\end{array}$ & $\begin{array}{c}\text { Specific } \\
\text { activity } \\
(\mathbf{U} / \mathbf{m g})\end{array}$ & $\begin{array}{c}\text { Recovery } \\
(\mathbf{\%})\end{array}$ & $\begin{array}{c}\text { Loss in } \\
\text { enzyme } \\
\text { activity } \\
(\boldsymbol{\%})\end{array}$ \\
\cline { 2 - 3 } & In cells & In supernatant & 4.04 & 0.073 & 42 & $\mathbf{1 3}$ \\
\hline $\begin{array}{c}\text { Before cell } \\
\text { disruption }\end{array}$ & 7.13 & ND & & & \\
\hline $\begin{array}{c}\text { After cell } \\
\text { disruption }\end{array}$ & $\mathbf{5 . 9 6}$ & $\mathbf{0 . 8 9}$ & & & & \\
\hline
\end{tabular}

Table.2 Alkali lysis of the resting cells of S. marcescens MTCC 97

\begin{tabular}{|c|c|c|c|c|c|c|}
\hline \multirow[t]{2}{*}{ Conditions } & \multicolumn{2}{|c|}{$\begin{array}{c}\text { Enzyme Activity } \\
\text { (U) }\end{array}$} & $\begin{array}{l}\text { Released } \\
\text { Protein }\end{array}$ & $\begin{array}{l}\text { Specific } \\
\text { activity }\end{array}$ & $\begin{array}{c}\text { Recovery } \\
(\%)\end{array}$ & $\begin{array}{c}\text { Loss in } \\
\text { enzyme }\end{array}$ \\
\hline & In cells & In supernatant & \multirow{3}{*}{3.55} & \multirow{3}{*}{0.030} & \multirow{3}{*}{6} & \multirow{3}{*}{38} \\
\hline $\begin{array}{l}\text { Before cell } \\
\text { disruption }\end{array}$ & 7.74 & ND & & & & \\
\hline $\begin{array}{l}\text { After cell } \\
\text { disruption }\end{array}$ & 4.30 & 0.48 & & & & \\
\hline
\end{tabular}

Table.3 Lysis of resting cells of S. marcescens MTCC 97 by acetone powder method

\begin{tabular}{|c|c|c|c|c|c|c|}
\hline \multirow{2}{*}{ Conditions } & \multicolumn{2}{|c|}{$\begin{array}{c}\text { Enzyme activity } \\
(\mathbf{U})\end{array}$} & $\begin{array}{c}\text { Released } \\
\text { protein } \\
(\mathbf{m g} / \mathbf{m l})\end{array}$ & $\begin{array}{c}\text { Specific } \\
\text { activity } \\
(\mathbf{U} / \mathbf{m g})\end{array}$ & $\begin{array}{c}\text { Recovery } \\
(\mathbf{\%})\end{array}$ & $\begin{array}{c}\text { Loss in enzyme } \\
\text { activity (\%) }\end{array}$ \\
\cline { 2 - 3 } & In cells & In supernatant & & & & \\
\hline $\begin{array}{c}\text { Before cell } \\
\text { disruption }\end{array}$ & 8.06 & ND & 6.58 & 0.021 & 17 & $\mathbf{3 0}$ \\
\hline $\begin{array}{c}\text { After cell } \\
\text { disruption }\end{array}$ & $\mathbf{4 . 3 0}$ & $\mathbf{1 . 3 7}$ & & & \\
\hline
\end{tabular}

Table.4 Lysis of resting cells of S. marcescens MTCC 97 by Triton X-100 and Guanidine- $\mathrm{HCl}$ treatment

\begin{tabular}{|c|c|c|c|c|c|c|}
\hline \multirow[t]{2}{*}{ Conditions } & \multicolumn{2}{|c|}{$\begin{array}{c}\text { Enzyme activity } \\
\text { (U) }\end{array}$} & $\begin{array}{c}\text { Released } \\
\text { protein }\end{array}$ & $\begin{array}{l}\text { Specific } \\
\text { activity }\end{array}$ & $\begin{array}{c}\text { Recovery } \\
(\%)\end{array}$ & $\begin{array}{c}\text { Loss in enzyme } \\
\text { activity (\%) }\end{array}$ \\
\hline & In cells & In supernatant & \multirow{3}{*}{2.47} & \multirow{3}{*}{0.007} & \multirow{3}{*}{3} & \multirow{3}{*}{12} \\
\hline $\begin{array}{l}\text { Before cell } \\
\text { disruption }\end{array}$ & 9.57 & ND & & & & \\
\hline $\begin{array}{l}\text { After cell } \\
\text { disruption }\end{array}$ & 8.17 & 0.26 & & & & \\
\hline
\end{tabular}


Table.5 Disintegration of resting cells of $S$. marcescens MTCC 97 in motar and pestle

\begin{tabular}{|c|c|c|c|c|c|c|}
\hline \multirow{2}{*}{ Conditions } & \multicolumn{2}{|c|}{$\begin{array}{c}\text { Enzyme activity } \\
\text { (U) }\end{array}$} & $\begin{array}{c}\text { Released } \\
\text { protein } \\
\text { (mg/ml) }\end{array}$ & $\begin{array}{c}\text { Specific } \\
\text { activity } \\
\text { (U/mg) }\end{array}$ & $\begin{array}{c}\text { Recovery } \\
(\%)\end{array}$ & $\begin{array}{c}\text { Loss in } \\
\text { enzyme } \\
\text { activity (\%) }\end{array}$ \\
\cline { 2 - 5 } & In cells & In supernatant & & & & \\
\hline $\begin{array}{c}\text { Before cell } \\
\text { disruption }\end{array}$ & 1.095 & ND & 6.62 & 0.031 & 26 & $\mathbf{8}$ \\
\hline $\begin{array}{c}\text { After cell } \\
\text { disruption }\end{array}$ & $\mathbf{0 . 0 7 2}$ & $\mathbf{3 . 0 9}$ & & & & \\
\hline
\end{tabular}

Table.6 Disintegration of resting cells of $S$. marcescens MTCC 97 by vortexing with glass beads

\begin{tabular}{|c|c|c|c|c|c|c|}
\hline \multirow{2}{*}{ Conditions } & \multicolumn{2}{|c|}{$\begin{array}{c}\text { Enzyme Activity } \\
\text { (U) }\end{array}$} & $\begin{array}{c}\text { Released } \\
\text { protein } \\
\text { (mg/ml) }\end{array}$ & $\begin{array}{c}\text { Specific } \\
\text { activity } \\
\text { (U/mg) }\end{array}$ & $\begin{array}{c}\text { Recovery } \\
(\mathbf{\%})\end{array}$ & $\begin{array}{c}\text { Loss in } \\
\text { enzyme } \\
\text { activity (\%) }\end{array}$ \\
\cline { 2 - 4 } & In cells & In supernatant & & & & \\
\hline $\begin{array}{c}\text { Before cell } \\
\text { disruption }\end{array}$ & 1.095 & ND & 6.26 & 0.043 & 29 & $\mathbf{5}$ \\
\hline $\begin{array}{c}\text { After cell } \\
\text { disruption }\end{array}$ & $\mathbf{0 . 0 7 2}$ & $\mathbf{3 . 4 5}$ & & & & \\
\hline
\end{tabular}

Table.7 Disintegration of resting cells of S. marcescens MTCC 97 by Zirconium beads (0.5mm)

\begin{tabular}{|c|c|c|c|c|c|c|}
\hline Conditions & \multicolumn{2}{|c|}{$\begin{array}{c}\text { Enzyme activity } \\
\text { (U) }\end{array}$} & $\begin{array}{c}\text { Released } \\
\text { protein } \\
\text { (mg/ml) }\end{array}$ & $\begin{array}{c}\text { Specific } \\
\text { activity } \\
(\mathbf{U} / \mathbf{m g})\end{array}$ & $\begin{array}{c}\text { Recovery } \\
(\mathbf{\%})\end{array}$ & $\begin{array}{c}\text { Loss in } \\
\text { enzyme } \\
\text { activity (\%) }\end{array}$ \\
\cline { 2 - 5 } & $\begin{array}{c}\text { In } \\
\text { cells }\end{array}$ & $\begin{array}{c}\text { In } \\
\text { supernatant }\end{array}$ & & & & \\
\hline $\begin{array}{c}\text { Before cell } \\
\text { disruption }\end{array}$ & 33.54 & ND & 7.20 & 0.029 & 28 & $\mathbf{6 4}$ \\
\hline $\begin{array}{c}\text { After cell } \\
\text { disruption }\end{array}$ & $\mathbf{2 . 5 8}$ & $\mathbf{9 . 4 8}$ & & & & \\
\hline
\end{tabular}

Table.8 Disintegration of resting cells of $S$. marcescens MTCC 97 by Glass beads $(0.5 \mathrm{~mm})$

\begin{tabular}{|c|c|c|c|c|c|c|}
\hline \multirow{2}{*}{ Conditions } & \multicolumn{2}{|c|}{$\begin{array}{c}\text { Enzyme activity } \\
\text { (U) }\end{array}$} & $\begin{array}{c}\text { Released } \\
\text { protein } \\
(\mathbf{m g} / \mathbf{m l})\end{array}$ & $\begin{array}{c}\text { Specific } \\
\text { activity } \\
\text { (U/mg) }\end{array}$ & $\begin{array}{c}\text { Recovery } \\
(\mathbf{\%})\end{array}$ & $\begin{array}{c}\text { Loss in } \\
\text { enzyme } \\
\text { activity (\%) }\end{array}$ \\
\cline { 2 - 5 } & In cells & In supernatant & & & & \\
\hline $\begin{array}{c}\text { Before cell } \\
\text { disruption }\end{array}$ & 33.40 & ND & 13.28 & 0.017 & 24 & $\mathbf{7 2}$ \\
\hline $\begin{array}{c}\text { After cell } \\
\text { disruption }\end{array}$ & $\mathbf{1 . 1 8}$ & $\mathbf{8 . 2 9}$ & & & \\
\hline
\end{tabular}


Table.9 Disintegration of resting cells of $S$. marcescens MTCC 97 by Glass beads $(0.1 \mathrm{~mm})$

\begin{tabular}{|c|c|c|c|c|c|c|}
\hline Conditions & \multicolumn{2}{|c|}{$\begin{array}{c}\text { Enzyme activity } \\
(\mathbf{U})\end{array}$} & $\begin{array}{c}\text { Released } \\
\text { protein } \\
(\mathbf{m g} / \mathbf{m l})\end{array}$ & $\begin{array}{c}\text { Specific } \\
\text { activity } \\
(\mathbf{U} / \mathbf{m g})\end{array}$ & $\begin{array}{c}\text { Recovery } \\
(\mathbf{\%})\end{array}$ & $\begin{array}{c}\text { Loss in } \\
\text { enzyme } \\
\text { activity } \\
(\mathbf{\%})\end{array}$ \\
\hline & In cells & In supernatant & & & & \\
\hline $\begin{array}{c}\text { Before cell } \\
\text { disruption }\end{array}$ & 38.27 & $\mathrm{ND}$ & 16.67 & 0.032 & 50 & $\mathbf{4 8}$ \\
\hline $\begin{array}{c}\text { After cell } \\
\text { disruption }\end{array}$ & $\mathbf{0 . 8 6}$ & $\mathbf{1 9 . 2}$ & & & & \\
\hline
\end{tabular}

Table.10 Disintegration of resting cells of $S$. marcescens MTCC 97 by Sonication

\begin{tabular}{|c|c|c|c|c|c|c|}
\hline \multirow[t]{2}{*}{ Conditions } & \multicolumn{2}{|c|}{$\begin{array}{l}\text { Enzyme activity } \\
\text { (U) }\end{array}$} & $\begin{array}{c}\text { Released } \\
\text { protein }\end{array}$ & $\begin{array}{l}\text { Specific } \\
\text { activity }\end{array}$ & $\begin{array}{c}\text { Recovery } \\
(\%)\end{array}$ & $\begin{array}{l}\text { Loss in } \\
\text { enzyme }\end{array}$ \\
\hline & In cells & In supernatant & \multirow{3}{*}{19.06} & \multirow{3}{*}{0.047} & \multirow{3}{*}{68} & \multirow{3}{*}{8} \\
\hline $\begin{array}{l}\text { Before cell } \\
\text { disruption }\end{array}$ & 48.16 & ND & & & & \\
\hline $\begin{array}{l}\text { After cell } \\
\text { disruption }\end{array}$ & 18.00 & 27.00 & & & & \\
\hline
\end{tabular}

Table.11 Disintegration of resting cells of S. marcescens MTCC 97 by Sonication at different cycles

\begin{tabular}{|c|c|c|c|}
\hline $\begin{array}{c}\text { Cycle } \\
\text { number }\end{array}$ & $\begin{array}{c}\text { Enzyme } \\
\text { activity } \\
(\mathbf{U})\end{array}$ & $\begin{array}{c}\text { Protein } \\
\text { released } \\
(\mathbf{m g} / \mathbf{m l})\end{array}$ & $\begin{array}{c}\text { Specific } \\
\text { activity } \\
\text { (U/mg) }\end{array}$ \\
\hline $\mathbf{1}$ & 0.21 & 5.336 & $\mathbf{0 . 0 3 9}$ \\
\hline $\mathbf{2}$ & 0.32 & 9.032 & $\mathbf{0 . 0 3 6}$ \\
\hline $\mathbf{3}$ & 0.49 & 13.07 & $\mathbf{0 . 0 3 7}$ \\
\hline $\mathbf{4}$ & 0.56 & 15.66 & $\mathbf{0 . 0 3 6}$ \\
\hline $\mathbf{5}$ & 0.65 & 15.36 & $\mathbf{0 . 0 4 2}$ \\
\hline $\mathbf{6}$ & 0.73 & 16.90 & $\mathbf{0 . 0 4 3}$ \\
\hline $\mathbf{7}$ & 0.73 & 20.17 & $\mathbf{0 . 0 3 6}$ \\
\hline $\mathbf{8}$ & 0.85 & 19.77 & $\mathbf{0 . 0 4 3}$ \\
\hline $\mathbf{9}$ & 0.87 & 19.06 & $\mathbf{0 . 0 4 7}$ \\
\hline $\mathbf{1 0}$ & 0.86 & 21.39 & $\mathbf{0 . 0 4 0}$ \\
\hline $\mathbf{1 1}$ & 0.85 & 21.71 & $\mathbf{0 . 0 3 9}$ \\
\hline $\mathbf{1 2}$ & $\mathbf{0 . 8 7}$ & $\mathbf{2 2 . 0 1}$ & $\mathbf{0 . 0 3 9}$ \\
\hline
\end{tabular}


Table.12 Disintegration of resting cells of S. marcescens MTCC 97 by sonication at different cell concentration

A. Cell concentration $=2.15 \mathrm{mg} / \mathrm{ml}$

\begin{tabular}{|c|c|c|c|c|c|c|}
\hline \multirow{2}{*}{ Conditions } & \multicolumn{2}{|c|}{$\begin{array}{c}\text { Enzyme activity } \\
(\mathbf{U})\end{array}$} & $\begin{array}{c}\text { Released } \\
\text { protein } \\
(\mathbf{m g} / \mathbf{m l})\end{array}$ & $\begin{array}{c}\text { Specific } \\
\text { activity } \\
(\mathbf{U} / \mathbf{m g})\end{array}$ & $\begin{array}{c}\text { Recovery } \\
(\mathbf{\%}\end{array}$ & $\begin{array}{c}\text { Loss in } \\
\text { Enzyme } \\
\text { activity } \\
(\mathbf{\%})\end{array}$ \\
\cline { 2 - 4 } & In cells & In supernatant & & & & \\
\hline $\begin{array}{c}\text { Before cell } \\
\text { disruption }\end{array}$ & 6.71 & ND & 4.23 & 0.011 & 27 & 46 \\
\hline $\begin{array}{c}\text { After cell } \\
\text { disruption }\end{array}$ & $\mathbf{1 . 8 1}$ & $\mathbf{1 . 8 0}$ & & & & \\
\hline
\end{tabular}

B. Cell concentration $=4.30 \mathrm{mg} / \mathrm{ml}$

\begin{tabular}{|c|c|c|c|c|c|c|}
\hline \multirow{2}{*}{ Conditions } & \multicolumn{2}{|c|}{$\begin{array}{c}\text { Enzyme activity } \\
\text { (U) }\end{array}$} & $\begin{array}{c}\text { Released } \\
\text { protein } \\
(\mathbf{m g} / \mathbf{m l})\end{array}$ & $\begin{array}{c}\text { Specific } \\
\text { activity } \\
(\mathbf{U} / \mathbf{m g})\end{array}$ & $\begin{array}{c}\text { Recovery } \\
(\mathbf{\%})\end{array}$ & $\begin{array}{c}\text { Loss in } \\
\text { enzyme } \\
\text { activity (\%) }\end{array}$ \\
\cline { 2 - 5 } & In cells & In supernatant & 13.12 & 0.004 & 65 & $\mathbf{2 6}$ \\
\hline $\begin{array}{c}\text { Before cell } \\
\text { disruption }\end{array}$ & 14.62 & ND & & & & \\
\hline $\begin{array}{c}\text { After cell } \\
\text { disruption }\end{array}$ & $\mathbf{1 . 4 0}$ & $\mathbf{9 . 4 6}$ & & & & \\
\hline
\end{tabular}

C. Cell concentration $=6.45 \mathrm{mg} / \mathrm{ml}$

\begin{tabular}{|c|c|c|c|c|c|c|}
\hline \multirow{2}{*}{ Conditions } & \multicolumn{2}{|c|}{$\begin{array}{c}\text { Enzyme activity } \\
\text { (U) }\end{array}$} & $\begin{array}{c}\text { Released } \\
\text { protein } \\
(\mathbf{m g} / \mathbf{m l})\end{array}$ & $\begin{array}{c}\text { Specific } \\
\text { activity } \\
(\mathbf{U} / \mathbf{m g})\end{array}$ & $\begin{array}{c}\text { Recovery } \\
(\boldsymbol{\%})\end{array}$ & $\begin{array}{c}\text { Loss in } \\
\text { Enzyme } \\
\text { activity } \\
(\mathbf{\%})\end{array}$ \\
\cline { 2 - 7 } & In cells & In supernatant & & & & \\
\hline $\begin{array}{c}\text { Before cell } \\
\text { disruption }\end{array}$ & 20.64 & ND & 16.60 & 0.009 & 29 & $\mathbf{3 4}$ \\
\hline $\begin{array}{c}\text { After cell } \\
\text { disruption }\end{array}$ & $\mathbf{7 . 7 4}$ & $\mathbf{5 . 9 2}$ & & & & \\
\hline
\end{tabular}

D. Cell concentration $=8.60 \mathrm{mg} / \mathrm{ml}$

\begin{tabular}{|c|c|c|c|c|c|c|}
\hline \multirow{2}{*}{ Conditions } & \multicolumn{2}{|c|}{$\begin{array}{c}\text { Enzyme activity } \\
\text { (U) }\end{array}$} & $\begin{array}{c}\text { Released } \\
\text { protein } \\
\text { (mg/ml) }\end{array}$ & $\begin{array}{c}\text { Specific } \\
\text { activity } \\
\text { (U/mg) }\end{array}$ & $\begin{array}{c}\text { Recovery } \\
(\%)\end{array}$ & $\begin{array}{c}\text { Loss in } \\
\text { enzyme } \\
\text { activity (\%) }\end{array}$ \\
\cline { 2 - 4 } & In cells & In supernatant & & & & \\
\hline $\begin{array}{c}\text { Before cell } \\
\text { disruption }\end{array}$ & 31.99 & ND & 18.90 & 0.024 & 57 & 17 \\
\hline $\begin{array}{c}\text { After cell } \\
\text { disruption }\end{array}$ & $\mathbf{8 . 6 0}$ & $\mathbf{1 8 . 2 4}$ & & & & \\
\hline
\end{tabular}


E. Cell concentration $=10.75 \mathrm{mg} / \mathrm{ml}$

\begin{tabular}{|c|c|c|c|c|c|c|}
\hline \multirow{2}{*}{ Conditions } & \multicolumn{2}{|c|}{$\begin{array}{c}\text { Enzyme activity } \\
\text { (U) }\end{array}$} & $\begin{array}{c}\text { Released } \\
\text { protein } \\
(\mathbf{m g} / \mathbf{m l})\end{array}$ & $\begin{array}{c}\text { Specific } \\
\text { activity } \\
\text { (U/mg) }\end{array}$ & $\begin{array}{c}\text { Recovery } \\
(\%)\end{array}$ & $\begin{array}{c}\text { Loss in } \\
\text { enzyme } \\
\text { activity (\%) }\end{array}$ \\
\cline { 2 - 6 } & In cells & In supernatant & & & & \\
\hline $\begin{array}{c}\text { Before cell } \\
\text { disruption }\end{array}$ & 51.60 & ND & 19.05 & 0.046 & 68 & $\mathbf{8}$ \\
\hline $\begin{array}{c}\text { After cell } \\
\text { disruption }\end{array}$ & $\mathbf{1 2 . 9}$ & $\mathbf{3 4 . 8 4}$ & & & & \\
\hline
\end{tabular}

F. Cell concentration $=12.09 \mathrm{mg} / \mathrm{ml}$

\begin{tabular}{|c|c|c|c|c|c|c|}
\hline Conditions & \multicolumn{2}{|c|}{$\begin{array}{c}\text { Enzyme activity } \\
\text { (U) }\end{array}$} & $\begin{array}{c}\text { Released } \\
\text { protein } \\
\text { (mg/ml) }\end{array}$ & $\begin{array}{c}\text { Specific } \\
\text { activity } \\
(\mathbf{U} / \mathbf{m g})\end{array}$ & $\begin{array}{c}\text { Recovery } \\
(\%)\end{array}$ & $\begin{array}{c}\text { Loss in } \\
\text { enzyme } \\
\text { activity (\%) }\end{array}$ \\
\cline { 2 - 3 } & In cells & In supernatant & & & & \\
\hline $\begin{array}{c}\text { Before cell } \\
\text { disruption }\end{array}$ & 62.43 & ND & 19.61 & 0.040 & 53 & 16 \\
\hline $\begin{array}{c}\text { After cell } \\
\text { disruption }\end{array}$ & $\mathbf{1 9 . 6 1}$ & $\mathbf{3 3 . 0 0}$ & & & \\
\hline
\end{tabular}

G. Cell concentration $=15.05 \mathrm{mg} / \mathrm{ml}$

\begin{tabular}{|c|c|c|c|c|c|c|}
\hline \multirow{2}{*}{ Conditions } & \multicolumn{2}{|c|}{$\begin{array}{c}\text { Enzyme activity } \\
\text { (U) }\end{array}$} & $\begin{array}{c}\text { Released } \\
\text { protein } \\
\text { (mg/ml) }\end{array}$ & $\begin{array}{c}\text { Specific } \\
\text { activity } \\
(\mathbf{U} / \mathbf{m g})\end{array}$ & $\begin{array}{c}\text { Recovery } \\
(\mathbf{\%})\end{array}$ & $\begin{array}{c}\text { Loss in } \\
\text { enzyme } \\
\text { activity (\%) }\end{array}$ \\
\cline { 2 - 3 } & In cells & In supernatant & & & \\
\hline $\begin{array}{c}\text { Before cell } \\
\text { disruption }\end{array}$ & 77.06 & ND & 22.40 & 0.039 & 46 & 16 \\
\hline $\begin{array}{c}\text { After cell } \\
\text { disruption }\end{array}$ & $\mathbf{2 9 . 5 0}$ & $\mathbf{3 5 . 2 8}$ & & & & \\
\hline
\end{tabular}

Table 13 Disintegration of different volume of S. marcescens MTCC 97 cells by sonication A. Cell volume $=20 \mathrm{ml}$

\begin{tabular}{|c|c|c|c|c|c|c|}
\hline \multirow[t]{2}{*}{ Conditions } & \multicolumn{2}{|c|}{$\begin{array}{c}\text { Enzyme activity } \\
\text { (U) }\end{array}$} & $\begin{array}{c}\text { Released } \\
\text { protein }\end{array}$ & $\begin{array}{l}\text { Specific } \\
\text { activity }\end{array}$ & $\begin{array}{c}\text { Recovery } \\
(\%)\end{array}$ & $\begin{array}{l}\text { Loss in } \\
\text { enzyme }\end{array}$ \\
\hline & In cells & In supernatant & \multirow{3}{*}{18.59} & \multirow{3}{*}{0.015} & \multirow{3}{*}{21} & \multirow{3}{*}{55} \\
\hline $\begin{array}{l}\text { Before cell } \\
\text { disruption }\end{array}$ & 25.8 & ND & & & & \\
\hline $\begin{array}{l}\text { After cell } \\
\text { disruption }\end{array}$ & 6.00 & 5.50 & & & & \\
\hline
\end{tabular}


B. Cell volume $=30 \mathrm{ml}$

\begin{tabular}{|c|c|c|c|c|c|c|}
\hline \multirow[t]{2}{*}{ Conditions } & \multicolumn{2}{|c|}{$\begin{array}{l}\text { Enzyme activity } \\
\text { (U) }\end{array}$} & $\begin{array}{c}\text { Released } \\
\text { protein }\end{array}$ & $\begin{array}{l}\text { Specific } \\
\text { activity }\end{array}$ & $\begin{array}{l}\text { Recovery } \\
(\%)\end{array}$ & $\begin{array}{l}\text { Loss in } \\
\text { enzyme }\end{array}$ \\
\hline & In cells & In supernatant & \multirow{3}{*}{18.21} & \multirow{3}{*}{0.025} & \multirow{3}{*}{24} & \multirow{3}{*}{47} \\
\hline $\begin{array}{l}\text { Before cell } \\
\text { disruption }\end{array}$ & 38.70 & ND & & & & \\
\hline $\begin{array}{l}\text { After cell } \\
\text { disruption }\end{array}$ & 13.74 & 9.48 & & & & \\
\hline
\end{tabular}

C. Cell volume $=40 \mathrm{ml}$

\begin{tabular}{|c|c|c|c|c|c|c|}
\hline \multirow{2}{*}{ Conditions } & \multicolumn{2}{|c|}{$\begin{array}{c}\text { Enzyme activity } \\
\text { (U) }\end{array}$} & $\begin{array}{c}\text { Released } \\
\text { protein } \\
(\mathbf{m g} / \mathbf{m l})\end{array}$ & $\begin{array}{c}\text { Specific } \\
\text { activity } \\
\text { (U/mg) }\end{array}$ & $\begin{array}{c}\text { Recovery } \\
(\mathbf{\%})\end{array}$ & $\begin{array}{c}\text { Loss in enzyme } \\
\text { activity }(\mathbf{\%})\end{array}$ \\
\cline { 2 - 4 } & In cells & In supernatant & & & & \\
\hline $\begin{array}{c}\text { Before cell } \\
\text { disruption }\end{array}$ & 51.6 & ND & 19.01 & 0.046 & 68 & $\mathbf{8}$ \\
\hline $\begin{array}{c}\text { After cell } \\
\text { disruption }\end{array}$ & $\mathbf{1 2 . 9}$ & $\mathbf{3 4 . 8 4}$ & & & & \\
\hline
\end{tabular}

D. Cell volume $=50 \mathrm{ml}$

\begin{tabular}{|c|c|c|c|c|c|c|}
\hline Conditions & \multicolumn{2}{|c|}{$\begin{array}{c}\text { Enzyme activity } \\
\text { (U) }\end{array}$} & $\begin{array}{c}\text { Released } \\
\text { protein } \\
\text { (mg/ml) }\end{array}$ & $\begin{array}{c}\text { Specific } \\
\text { activity } \\
\text { (U/mg) }\end{array}$ & $\begin{array}{c}\text { Recovery } \\
(\%)\end{array}$ & $\begin{array}{c}\text { Loss in } \\
\text { enzyme } \\
\text { activity (\%) }\end{array}$ \\
\cline { 2 - 3 } & In cells & In supernatant & & & & \\
\hline $\begin{array}{c}\text { Before cell } \\
\text { disruption }\end{array}$ & 38.5 & ND & 19.45 & 0.039 & 60 & $\mathbf{7}$ \\
\hline $\begin{array}{c}\text { After cell } \\
\text { disruption }\end{array}$ & $\mathbf{2 1 . 5 0}$ & $\mathbf{3 5 . 0 0}$ & & & & \\
\hline
\end{tabular}

Table 14 Disintegration of S. marcescens MTCC 97 cells at different amplitudes of sonication A. Amplitude $=30 \%$

\begin{tabular}{|c|c|c|c|c|c|c|}
\hline \multirow{2}{*}{ Conditions } & \multicolumn{2}{|c|}{$\begin{array}{c}\text { Enzyme activity } \\
\text { (U) }\end{array}$} & $\begin{array}{c}\text { Released } \\
\text { protein } \\
\text { (mg/ml) }\end{array}$ & $\begin{array}{c}\text { Specific } \\
\text { activity } \\
\text { (U/mg) }\end{array}$ & $\begin{array}{c}\text { Recovery } \\
(\mathbf{\%})\end{array}$ & $\begin{array}{c}\text { Loss in } \\
\text { enzyme } \\
\text { activity (\%) }\end{array}$ \\
\cline { 2 - 6 } In cells & In supernatant & & & & \\
\hline $\begin{array}{c}\text { Before cell } \\
\text { disruption }\end{array}$ & 47.7 & ND & 17.72 & 0.02 & 26 & $\mathbf{2 7}$ \\
\hline $\begin{array}{c}\text { After cell } \\
\text { disruption }\end{array}$ & $\mathbf{2 4 . 5 1}$ & $\mathbf{1 3 . 2 0}$ & & & & \\
\hline
\end{tabular}


B. Amplitude $=35 \%$

\begin{tabular}{|c|c|c|c|c|c|c|}
\hline \multirow{2}{*}{ Conditions } & \multicolumn{2}{|c|}{$\begin{array}{c}\text { Enzyme activity } \\
\text { (U) }\end{array}$} & $\begin{array}{c}\text { Released } \\
\text { protein } \\
\text { (mg/ml) }\end{array}$ & $\begin{array}{c}\text { Specific } \\
\text { activity } \\
(\mathbf{U} / \mathbf{m g})\end{array}$ & $\begin{array}{c}\text { Recovery } \\
(\%)\end{array}$ & $\begin{array}{c}\text { Loss in } \\
\text { enzyme } \\
\text { activity (\%) }\end{array}$ \\
\cline { 2 - 4 } & In cells & In supernatant & & & & \\
\hline $\begin{array}{c}\text { Before cell } \\
\text { disruption }\end{array}$ & 47.7 & ND & 20.56 & 0.03 & 39 & \\
\hline $\begin{array}{c}\text { After cell } \\
\text { disruption }\end{array}$ & $\mathbf{2 0 . 6 4}$ & $\mathbf{1 9 . 9 6}$ & & & & \\
\hline
\end{tabular}

C. Amplitude $=39 \%$

\begin{tabular}{|c|c|c|c|c|c|c|}
\hline \multirow[t]{2}{*}{ Conditions } & \multicolumn{2}{|c|}{$\begin{array}{c}\text { Enzyme activity } \\
\text { (U) }\end{array}$} & $\begin{array}{l}\text { Released } \\
\text { protein }\end{array}$ & Specific & $\begin{array}{c}\text { Recovery } \\
(\%)\end{array}$ & $\begin{array}{l}\text { Loss in } \\
\text { enzyme }\end{array}$ \\
\hline & In cells & In supernatant & \multirow{3}{*}{19.05} & \multirow{3}{*}{0.046} & \multirow{3}{*}{68} & \multirow{3}{*}{8} \\
\hline $\begin{array}{l}\text { Before cell } \\
\text { disruption }\end{array}$ & 51.60 & ND & & & & \\
\hline $\begin{array}{l}\text { After cell } \\
\text { disruption }\end{array}$ & 12.9 & 34.84 & & & & \\
\hline
\end{tabular}

Table 15 Comparison of the various methods used for the cell disintegration of the resting cells of $S$. marcescens MTCC 97

\begin{tabular}{|c|c|c|c|c|c|}
\hline Methods & Treatments & $\begin{array}{c}\text { Released } \\
\text { protein } \\
(\mathrm{mg} / \mathrm{ml})\end{array}$ & $\begin{array}{l}\text { Specific } \\
\text { activity } \\
\text { (U/mg) }\end{array}$ & $\begin{array}{c}\text { Recovery } \\
(\%)\end{array}$ & $\begin{array}{c}\text { Loss in } \\
\text { enzyme } \\
\text { activity }(\%)\end{array}$ \\
\hline Enzymatic & Lysozyme & 4.04 & 0.073 & 42 & 13 \\
\hline \multirow{3}{*}{ Chemical } & Alkali lysis & 3.55 & 0.030 & 6 & 38 \\
\hline & Acetone powder & 6.58 & 0.021 & 17 & 30 \\
\hline & $\begin{array}{c}\text { Triton } \mathrm{X}-100 \text { and } \\
\text { Guanidine-HCl }\end{array}$ & 2.47 & 0.007 & 3 & 12 \\
\hline \multirow{4}{*}{ Physical } & Mortar and Pestle & 6.62 & 0.031 & 26 & 8 \\
\hline & Vortex & 6.26 & 0.043 & 29 & 5 \\
\hline & Bead beater & 16.67 & 0.032 & 50 & 48 \\
\hline & Sonicator & 19.06 & 0.047 & 68 & 8 \\
\hline
\end{tabular}


Table.16 Selection of buffer and $\mathrm{pH}$ for resting cells and cell free extract obtained from S. marcescens MTCC 97

\begin{tabular}{|c|c|c|c|c|c|c|c|c|c|c|c|c|c|c|}
\hline \multirow[t]{3}{*}{$\begin{array}{l}\text { Buffers } \\
\text { pH }\end{array}$} & \multicolumn{2}{|c|}{$\begin{array}{c}\text { Citrate } \\
\text { phosphate } \\
\text { buffer }\end{array}$} & \multicolumn{2}{|c|}{ Acetate buffer } & \multicolumn{2}{|c|}{$\begin{array}{c}\text { Sodium } \\
\text { phosphate } \\
\text { buffer }\end{array}$} & \multicolumn{2}{|c|}{$\begin{array}{c}\text { Potassium } \\
\text { phosphate } \\
\text { buffer }\end{array}$} & \multicolumn{2}{|c|}{ Citrate buffer } & \multicolumn{2}{|c|}{$\begin{array}{c}\text { Glycine } \mathrm{NaOH} \\
\text { buffer }\end{array}$} & \multicolumn{2}{|c|}{$\begin{array}{c}\text { Carbonate- } \\
\text { Bicarbonate } \\
\text { buffer }\end{array}$} \\
\hline & Enzyme & activity & Enzyme & activity & Enzyme & activity & Enzyme & activity & Enzyme & activity & Enzyme & activity & Enzym & activity \\
\hline & $\begin{array}{c}\text { Resting } \\
\text { Cells } \\
\text { U/mg } \\
\text { dcw }\end{array}$ & $\begin{array}{l}\text { Cell } \\
\text { free } \\
\text { extract } \\
(\mathrm{U} / \mathrm{ml})\end{array}$ & $\begin{array}{c}\text { Resting } \\
\text { Cells } \\
\text { U/mg } \\
\text { dcw }\end{array}$ & $\begin{array}{l}\text { Cell } \\
\text { free } \\
\text { extract } \\
(\mathrm{U} / \mathrm{ml})\end{array}$ & $\begin{array}{c}\text { Resting } \\
\text { cells } \\
\mathrm{U} / \mathrm{mg} \\
\text { dcw }\end{array}$ & $\begin{array}{l}\text { Cell } \\
\text { free } \\
\text { Extract } \\
(\mathrm{U} / \mathrm{ml})\end{array}$ & $\begin{array}{c}\text { Resting } \\
\text { Cells } \\
\text { U/mg } \\
\text { dcw }\end{array}$ & $\begin{array}{c}\text { Cell } \\
\text { free } \\
\text { Extract } \\
(\mathrm{U} / \mathrm{ml})\end{array}$ & $\begin{array}{c}\text { Resting } \\
\text { cells } \\
\mathrm{U} / \mathrm{mg} \\
\text { dcw }\end{array}$ & $\begin{array}{c}\text { Cell } \\
\text { free } \\
\text { Extract } \\
(\mathrm{U} / \mathrm{ml})\end{array}$ & $\begin{array}{c}\text { Resting } \\
\text { Cells } \\
\text { U/mg } \\
\text { dcw }\end{array}$ & $\begin{array}{c}\text { Cell } \\
\text { free } \\
\text { Extract } \\
(\mathrm{U} / \mathrm{ml})\end{array}$ & $\begin{array}{c}\text { Resting } \\
\text { Cells } \\
\text { U/mg } \\
\text { dcw }\end{array}$ & $\begin{array}{c}\text { Cell } \\
\text { free } \\
\text { extract } \\
(\mathbf{U} / \mathbf{m l})\end{array}$ \\
\hline 4.0 & NA & - & 0.020 & 0.173 & - & - & - & - & - & & - & - & - & - \\
\hline 4.5 & NA & - & 0.040 & 0.200 & - & - & - & - & 0.020 & 0.186 & - & - & - & - \\
\hline 5.0 & 0.038 & 0.083 & 0.049 & 0.441 & - & - & - & - & 0.062 & 0.156 & - & - & - & - \\
\hline 5.5 & 0.061 & 0.325 & 0.046 & 0.160 & - & - & - & - & 0.067 & 0.508 & - & - & - & - \\
\hline 6.0 & 0.075 & 0.492 & 0.041 & 0.118 & 0.029 & 0.185 & - & - & 0.075 & 0.396 & - & - & - & - \\
\hline 6.5 & 0.076 & 0.323 & - & - & 0.046 & 0.367 & - & - & 0.107 & 0.500 & - & - & - & - \\
\hline 7.0 & 0.035 & 0.205 & - & - & 0.100 & 0.473 & 0.038 & 0.246 & - & - & - & - & - & - \\
\hline 7.5 & - & - & - & - & 0.116 & 0.558 & 0.084 & 0.399 & - & - & - & - & - & - \\
\hline 8.0 & - & - & - & - & 0.069 & 0.366 & 0.102 & 0.497 & - & - & - & - & - & - \\
\hline 8.5 & - & - & - & - & - & - & 0.052 & 0.230 & - & - & - & - & - & - \\
\hline 9.0 & - & - & - & - & - & - & - & - & - & - & 0.006 & 0.020 & - & - \\
\hline 9.5 & - & - & - & - & - & - & - & - & - & - & 0.007 & 0.006 & 0.031 & 0.276 \\
\hline 10.0 & - & - & - & - & - & - & - & - & - & - & 0.007 & NA & 0.026 & 0.246 \\
\hline 10.5 & - & - & - & - & - & - & - & - & - & - & - & - & 0.023 & 0.213 \\
\hline
\end{tabular}




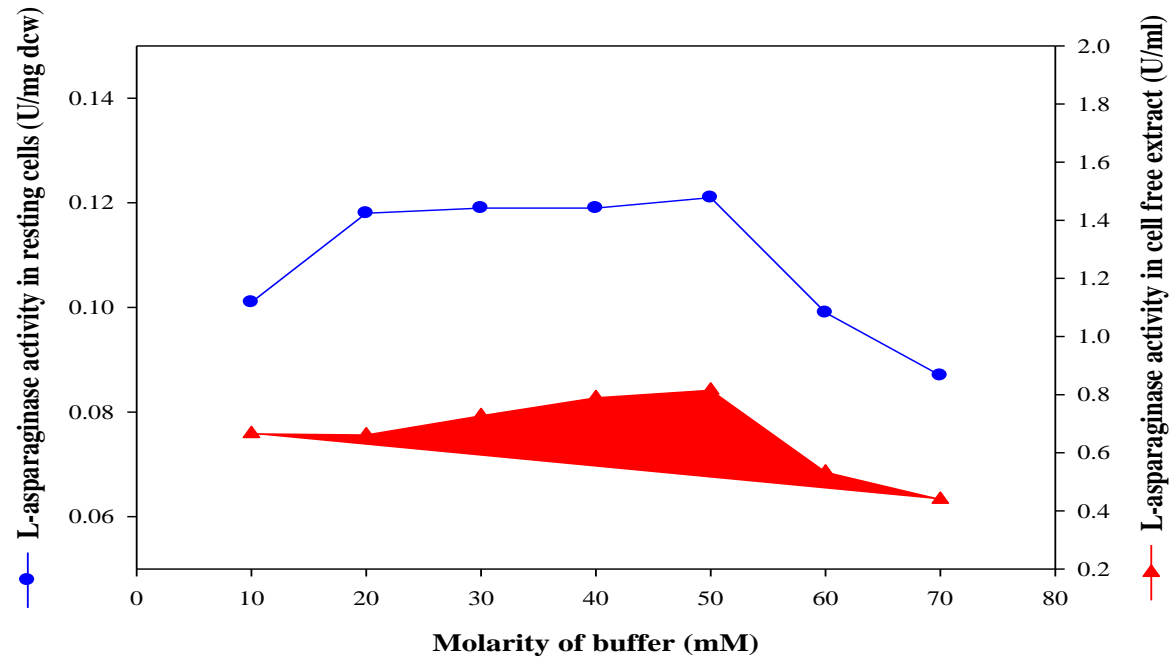

Fig.1 Effect of different concentration of sodium phosphate buffer on L-asparaginase activity of S. marcescens MTCC 97

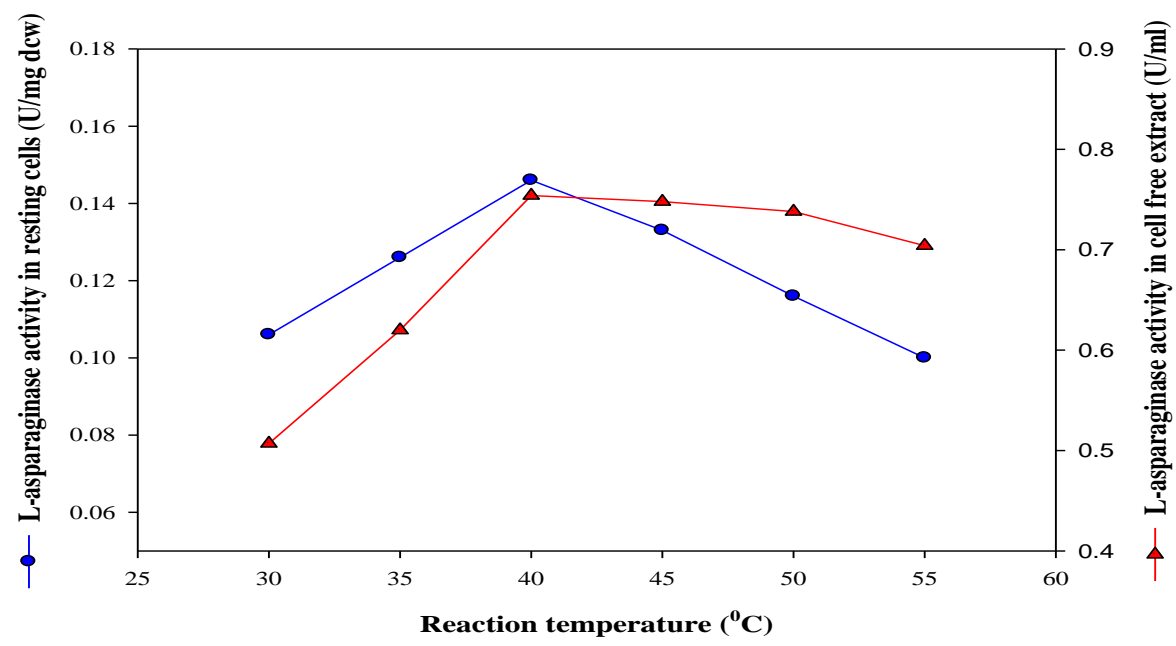

Fig.2 Effect of reaction temperature on L-asparaginase activity of $S$. marcescens MTCC 97

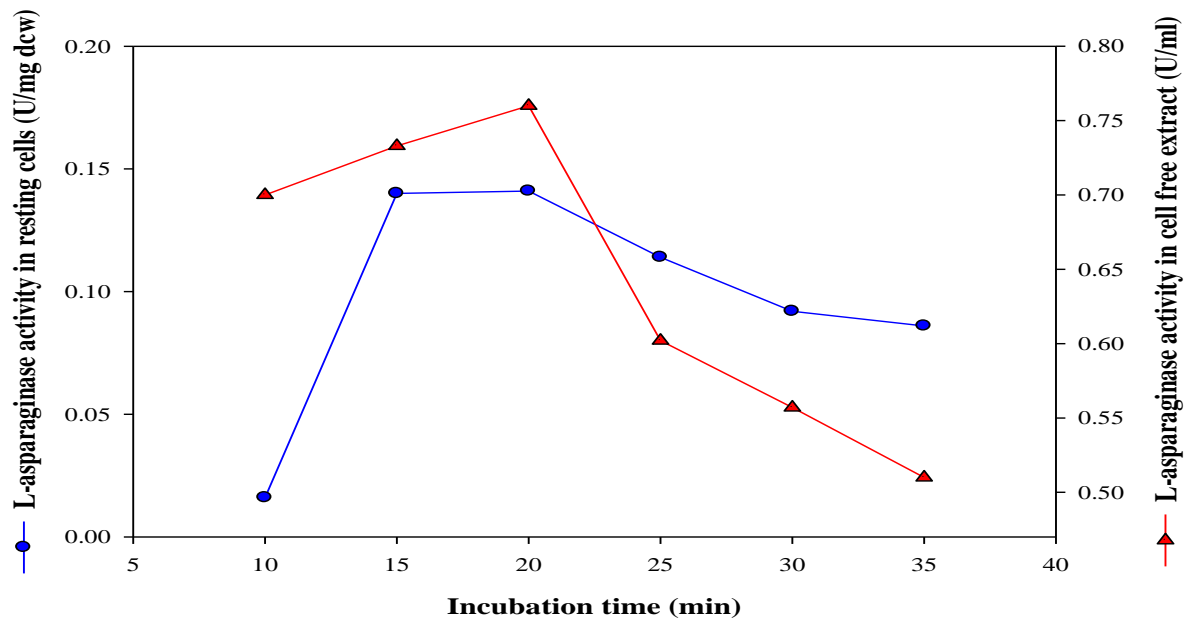

Fig.3 Effect of incubation time on L-asparaginase activity of S. marcescens MTCC 97 


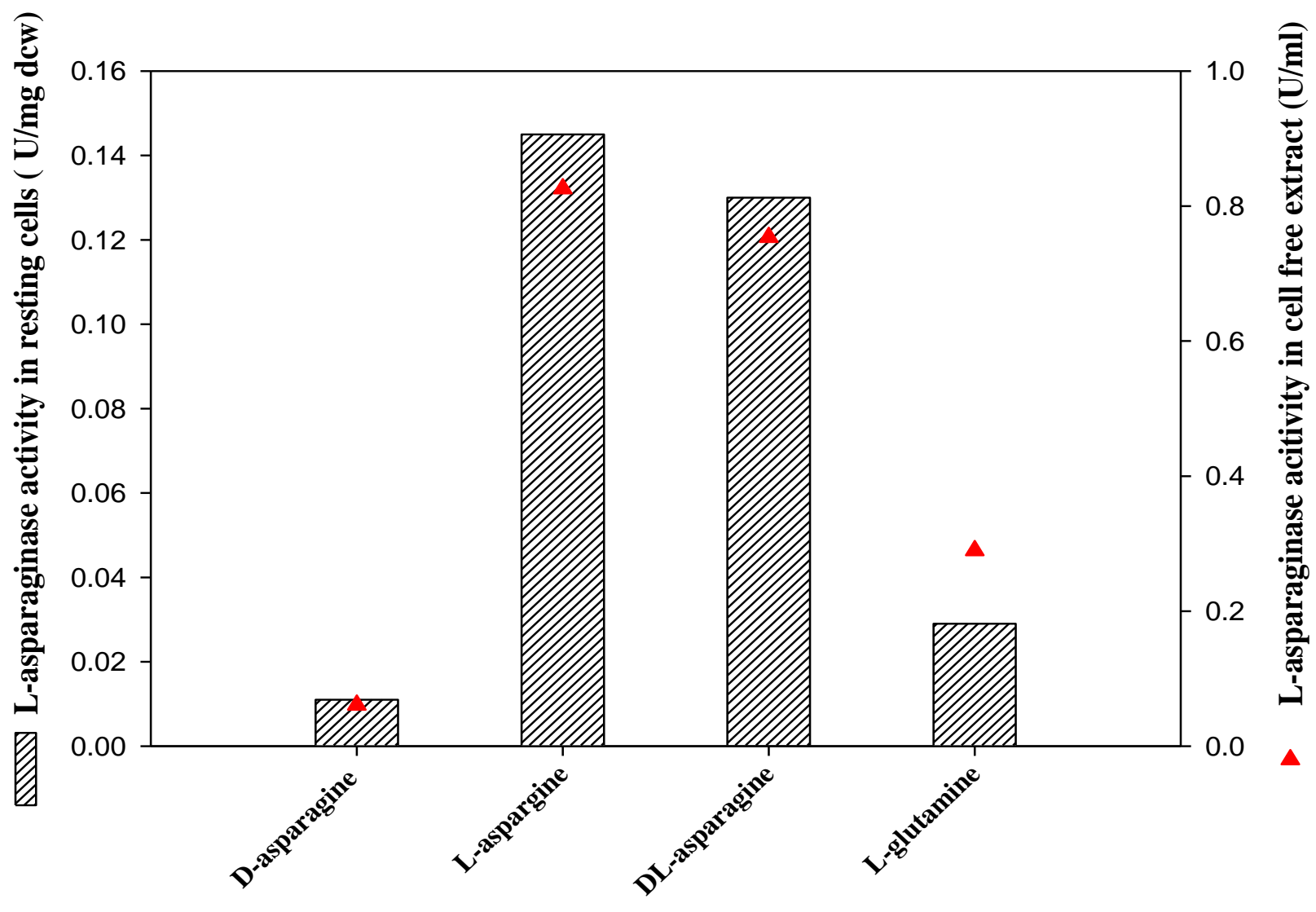

Substrate (10mM)

Fig.4 Substrate specificity of L-asparaginase from S. marcescens MTCC 97

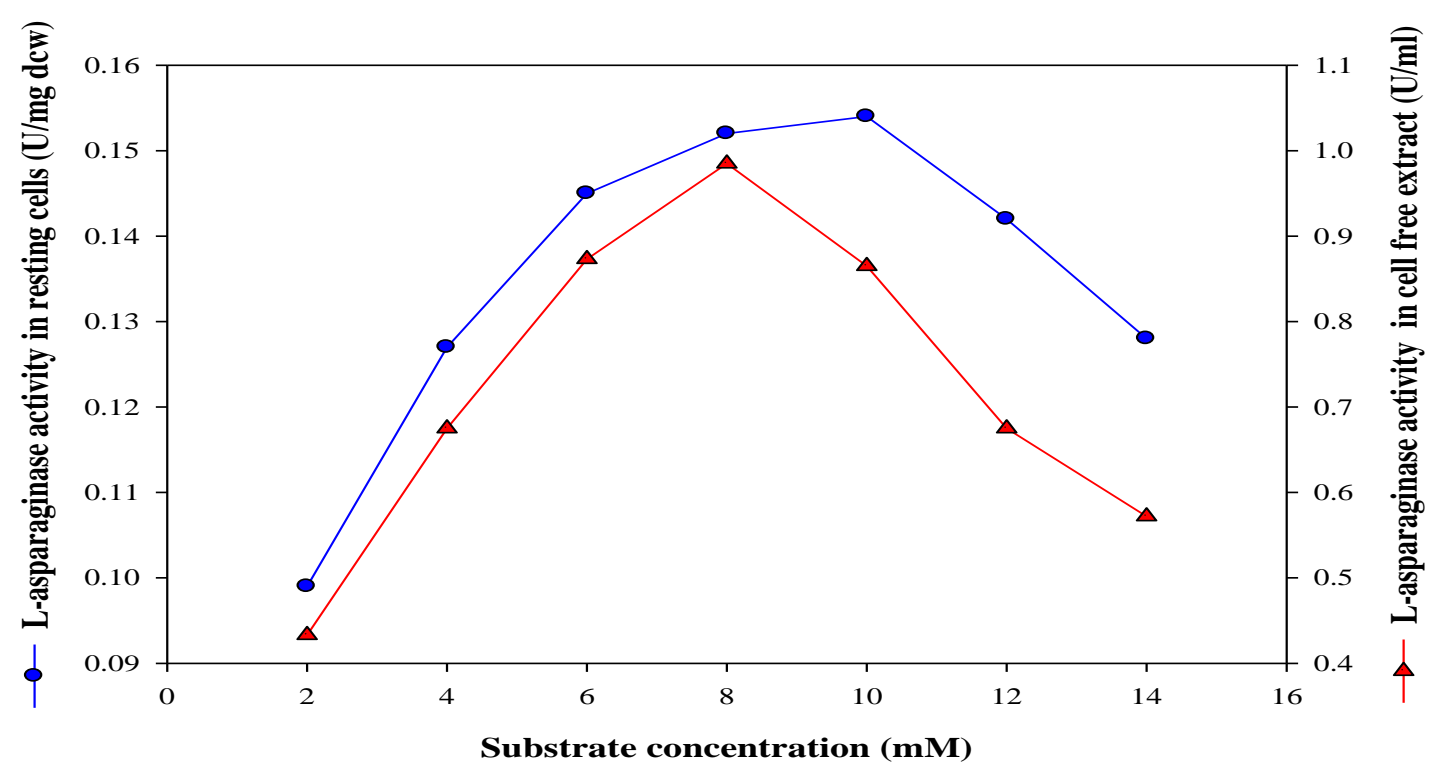

Fig.5 Effect of substrate concentration on L-asparaginase activity of S. marcescens MTCC 97 


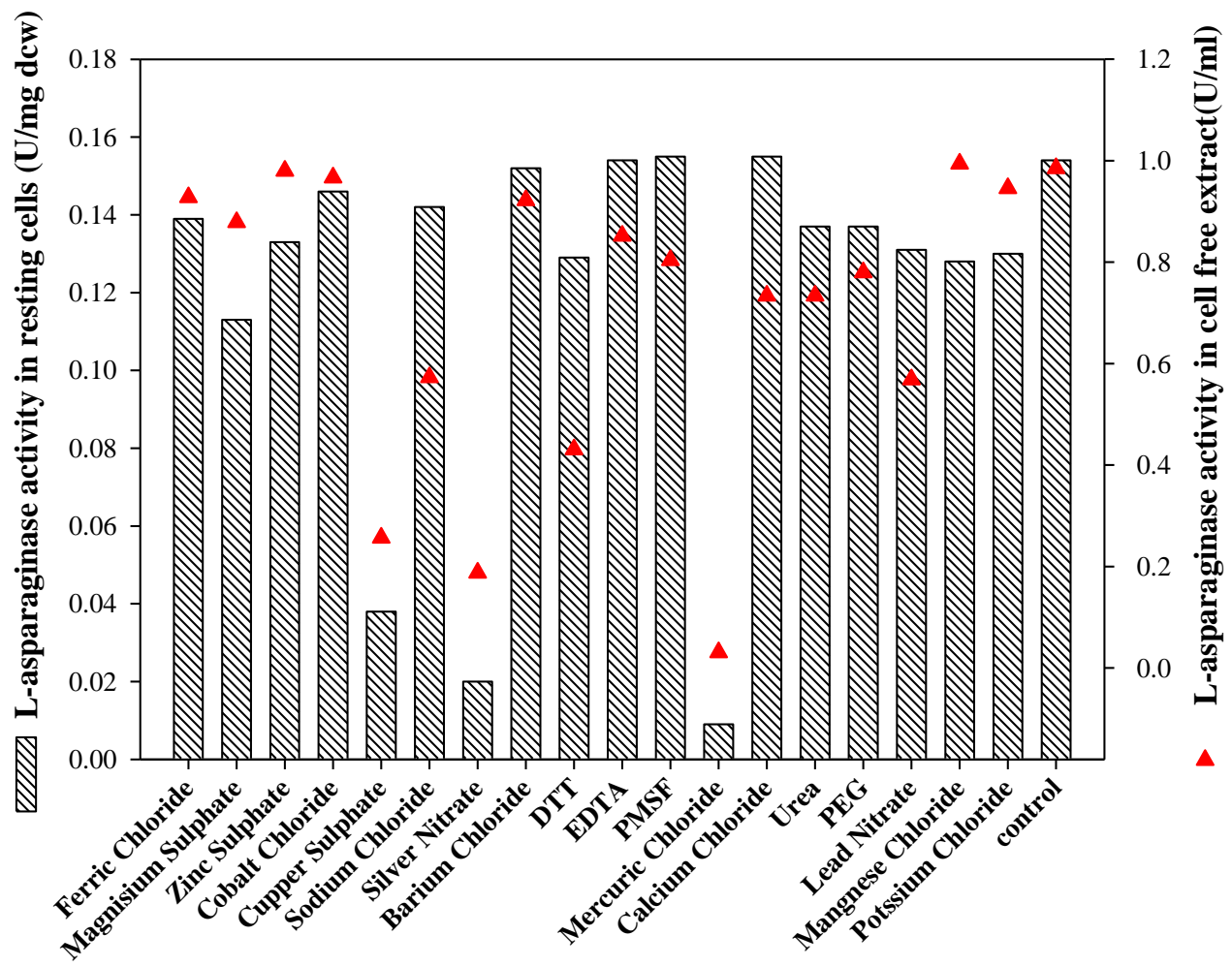

Metal inns (1mM)

Fig.6 Effect of metal ions, chelating agents and other additives on L-asparaginase activity of $S$. marcescens MTCC 97

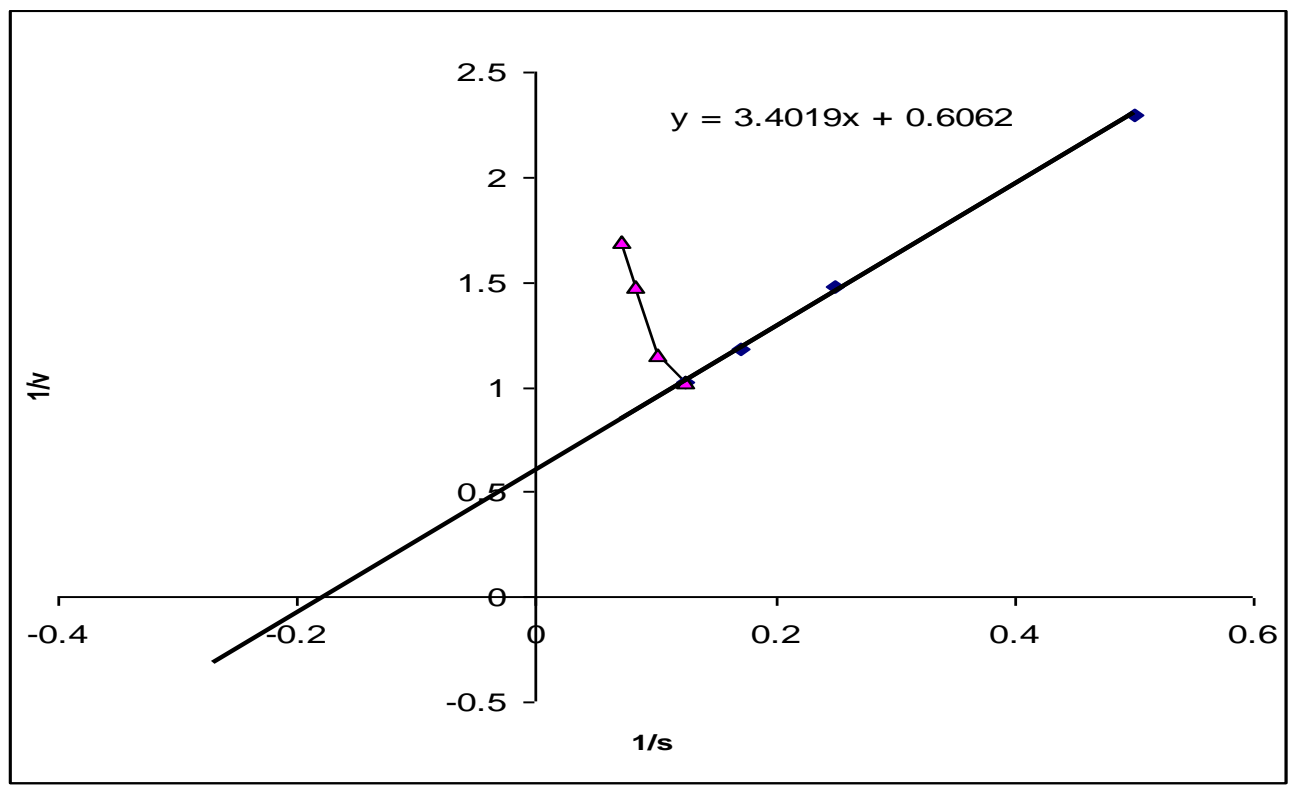

Fig.7 Line Weaver Burke plot for the L-asparaginase activity in the cell free extract of S. marcescens MTCC 97 


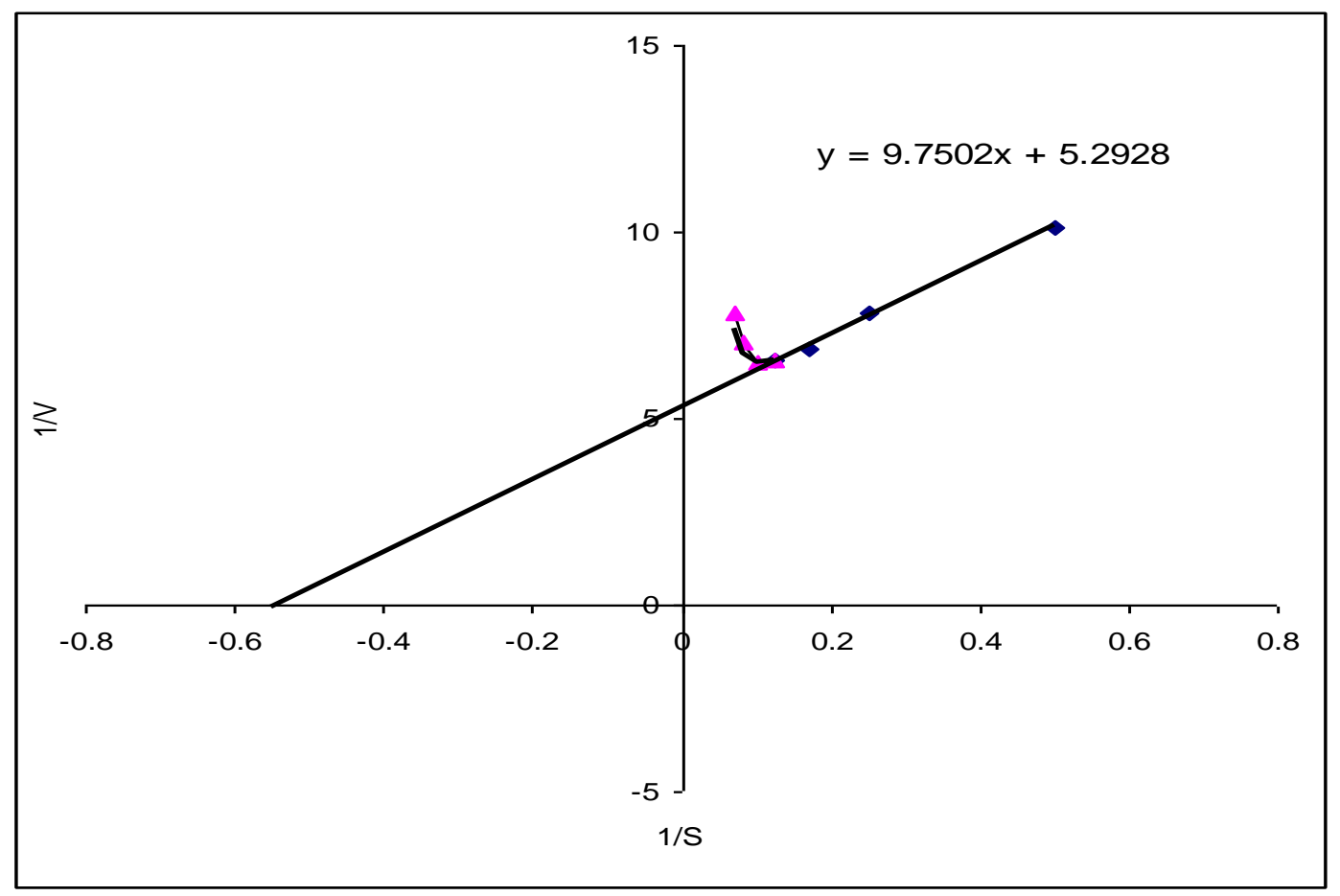

Fig.8 Line Weaver Burke plot for the L-asparaginase activity in the resting cells of S. marcescens MTCC 97

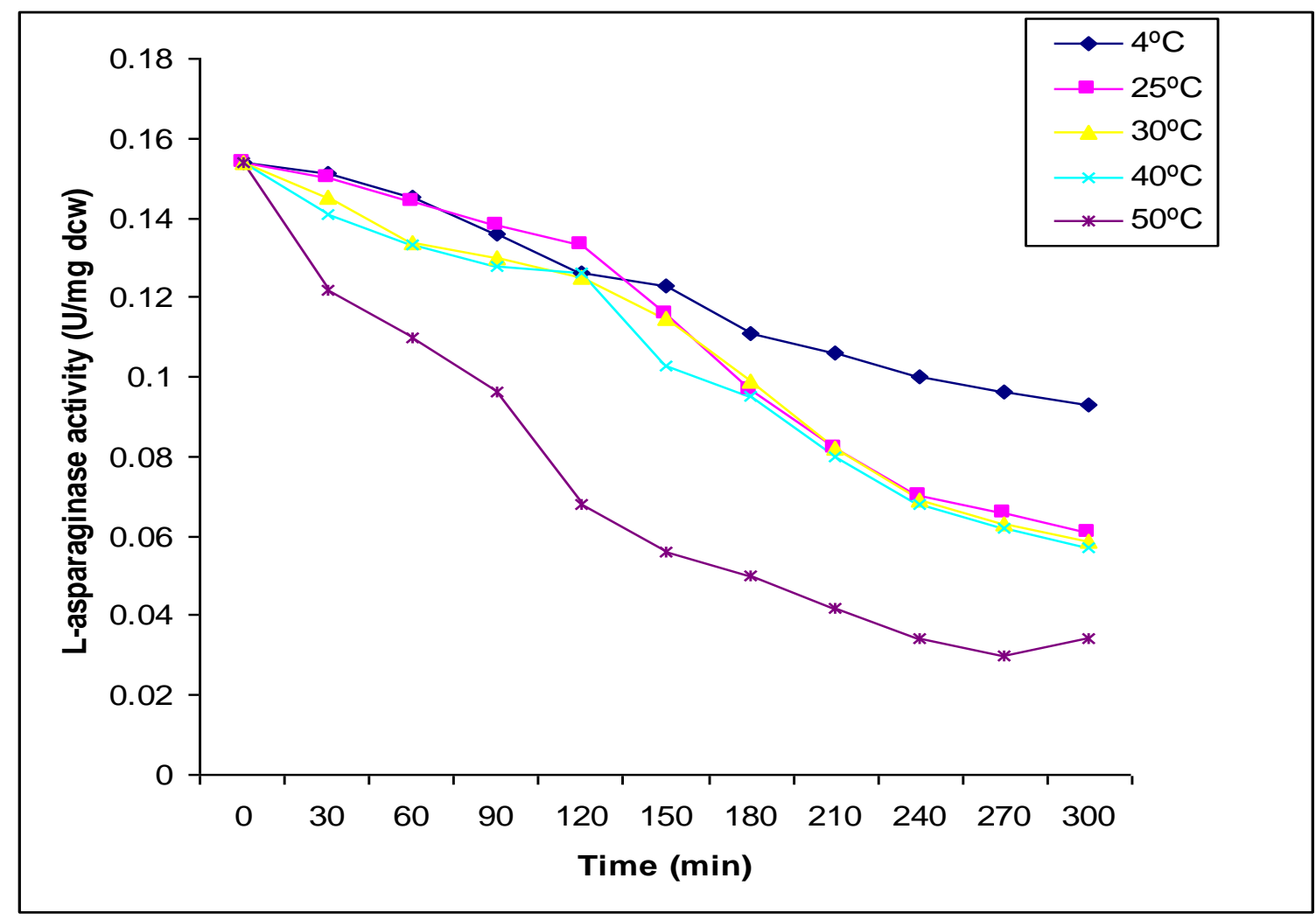

Fig.9 Stability profile of the resting cells of S. marcescens MTCC 97 


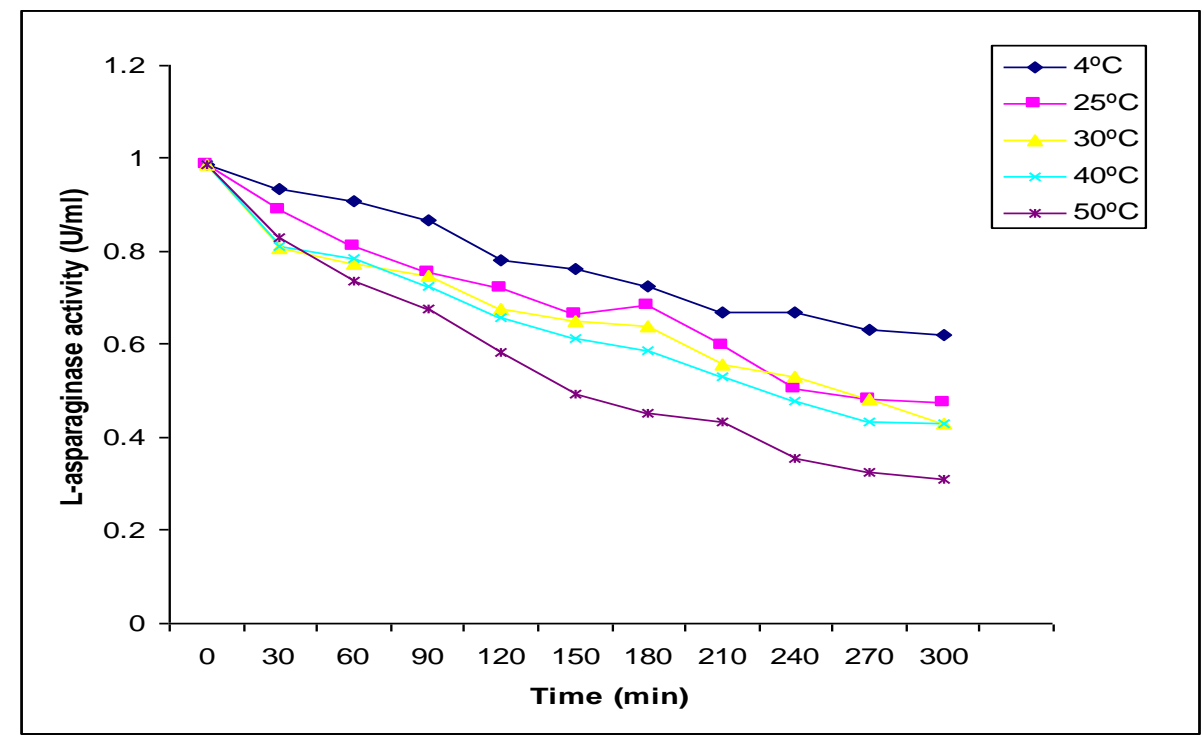

Fig.10 Stability profile of the cell free extract of S. marcescens MTCC 97

These findings suggest that the released Lasparaginase was more stable than the resting cells of S. marcescens MTCC 97. The thermal stability of L-asparaginase in resting cells and cell free extract of $S$. marcescens MTCC 97 were also established. At higher incubation temperature $\left(50^{\circ} \mathrm{C}\right)$ the half-life of $\mathrm{L}$ asparaginase in cell free extract and in resting cells was found to be 180 and $90 \mathrm{~min}$, respectively.

These findings suggest that the released Lasparaginase was more stable than the resting cells of S. marcescens MTCC 97.The Lasparaginase activity in Bacillus sp. decreased sharply above $40^{\circ} \mathrm{C}$ and the enzyme was inactivated at $50^{\circ} \mathrm{C}$ with a half a life period of about $1 \mathrm{~h}$ [34]. Commercial preparation of Lasparaginase, Elspar, was found to be very stable at $45^{\circ} \mathrm{C}-55^{\circ} \mathrm{C}[31]$.

The half-life of Elspar at $60^{\circ} \mathrm{C}$ is 25 minutes. The L-asparaginase is the first enzyme with antitumor activity to be intensively studies in human beings. The major application of Lasparaginase is as an injectible drug for the treatment of tumors or Lymphoblastic Leukemia in human beings. The sensitivity of application demands high degree of purity of this enzyme. Most of the microbial Lasparaginase is intracellular in nature except few, which are secreted outside the cells (Mohapatra BR et al., 1995). Hence, the disintegration of resting cells of $S$. marcescens MTCC 97 or any L-asparaginase producing microorganisms seems to be necessary and first step for large scale commercial production of this enzyme.

\section{Discussion}

On comparison with the various methods (enzymatic, chemical and physical) used for the cell disintegration of the resting cells of $S$. marcescens MTCC 97, sonication was found to be the most effective method for the release of intracellular L-asparaginase from $S$. marcescens MTCC 97 with the maximum specific activity $0.047 \mathrm{U} / \mathrm{mg}$ of protein (Table $15)$.

The recovery of L-asparaginase was found to be $68 \%$ with a loss of only $8 \%$. Amongst all the methods used, the bead beater and sonication were found to be the two most effective methods for the release of intracellular L-asparaginase from $S$. marcescens MTCC 97. The Bead beater was 
found to be an efficient means for cell lysis. Disintegration of resting cells of $S$. marcescens MTCC 97 by bead beater using $0.1 \mathrm{~mm}$ glass beads leads to the $50 \%$ recovery of the enzyme. The amount of released protein was found to be $16.67 \mathrm{mg} / \mathrm{ml}$. However, the loss of enzyme activity using bead beater was found to be very high $(48 \%)$ possibly due to the denaturation of enzyme by the generation of heat.

Bead agitation or bead milling has been frequently used in large scale to medium scale preparation of intracellular protein from microorganisms in which harvested cells are vigorously agitated with beads in a closed chamber [15]. Protein release in these devices depend upon the cell disruption caused by shear forces and collision between beads and can be described as first order process (Melenders AV et al., 1992).

The recovery of L-asparaginase using sonicator was found to be maximum (68\%) with overall loss of $8 \%$ in activity in 9 min. The recovery of L-asparaginase has found to be more than $80 \%$ by 10 min sonication in case of a recombinant strain of E. coli (Krasotkina $\mathrm{J}$ et al., 2004). Sonication being most efficient in the recovery of this membrane bound enzyme, recommended for its extraction from fresh bacterial biomass (Singh RS, 2013).

A remarkable feature of asparaginases is their pronounced antitumor activity, due to which these enzymes have found wide application in medicine as effective antitumor agents for the treatment of Acute Lymphoblastic Leukemia, lymphosarcomas, and reticulum cell sarcomas. Asparaginases are often successfully used when other antitumor drugs are ineffective. The antitumor effect of asparaginases is attributed to their ability to suppress asparagine metabolism, which is necessary for tumor cell growth (Sokolov NN et al., 2000). The modified asparaginase retained 57\% of initial activity. A simple and efficient pegylation procedure can be used for production of asparaginase with improved therapeutic properties (Kuchumova AV et al., 2006).

\section{Acknowledgments}

This study was supported by Department of Biotechnology, Himachal Pradesh University, Shimla.

\section{Compliance with Ethical Standards and Conflict of interest}

The authors declare no conflicts of interest associated with this manuscript.

\section{References}

Birnboim HC and Dolt J. 1979. A rapid alkaline extraction procedure for screening recombinant plasmid DNA Nucleic acid. Res. 7:1513.

Bradford MM. 1976. A Rapid and Sensitive Method for the Quantitation of Microgram Quantities of Protein Utilizing the Principle of Protein-Dye Binding. Ana. Biochem. 72:248.

Bucke C. 1983. The biotechnology of enzyme isolation and purification In: A Wiseman (Eds) Principles of Biotechnology. Surrey University Press Glasgow Scotland 151-171.

Chisti Y and Moo-Young M. 1991. Fermentation Technology, Bioprocessing, Scale-up and Manufacture. In Biotechnology: The Science and the Buisness; Moses V, Cape RE, (Eds) Hardwood Acadmic Publishers: New York.

Erbetta A, Salmaggi A and Sghirlanzoni A (2008) Clinical and radiological features of brain neurotoxicity caused by antitumor and immunosuppressant 
treatments. Neurol. Sci. 29:131-137.

Fawett JK and Scott JE. 1960. A rapid method for the determination of urea. J. Clin. Pathol. 13: 156-159.

Helenius A and Simons K.1975. Solublization of membranes by detergents. Biochem. Biophy. Acta. 415:29-39.

Hill JM. 1967. L-asparaginase therapy for leukemia and other malignant neoplasms. J. Am. Med. Assoc. 202: 882-888.

Hourani R, Abboud M, Hourani M, Khalifeh H, Mecwakkit S. 2008. L-asparaginase -induced posterior reversible encephalopathy syndrome during Acute Lymphoblastic Leukemia treatment in children. New Pediatr. 39:46-50.

Khushoo A, Pal Y, Sing BN and Mukharjee KJ. 2004. Extracellular expression and single step purification of recombinant Escherichia coli asparaginase II. Prot. Exp. Purifi. 38: 29-36.

Kirsop BH. 1981. Biotechnology in food processing industry. Chem. Ind: 218.

Krasotkina J, Borisova A, Gervaziev Y, Nikolay N and Sokolov. 2004. One step purification and kinetic properties of the recombinant L-asparaginase from Erwinia carotovora. Biotechnol. Appl. Biochem. 39: 215.

Kuchumova AV, Krasotkina YV, Khasigov PZ and Sokolov NN. 2006. Modification of Recombinant Asparaginase from Erwinia carotovora with Polyethylene Glycol 5000. ISSN 1990-7508, Biochemistry (Moscow) Supplement Series B: Biomed. Chem. 3: 230-232.

Kula MR and Schutte H. 1987. Purification of Proteins and the Disruption of Microbial Cells. Biotechnol. Prog: 3-31.

Lee SM, Wroble MH, Ross JT. 1989. Bioconversion of amino acids into flavouring alcohols and esters by Erwinia carotovora subsp. Atroseptica. Appl. Biochem. Biotechnol. 22:1-11.
Manna S and Gram C. 1995. Purification, characterization and antitumor activity of L-asparaginase isolated from Pseudomonas stutzeri MB-405. Curr. Microbiol. 30: 291-198.

Marchesi SL, Steers E, Marchesi VI and Tiliack TW. 1970. Physical and chemical properties of a proteins isolated from recombinant cell membranes. Biochem. 9:50-57.

Meister A, Levintow L, Greenfield RE and Abendschein PA. 1955. Hydrolysis and transfer reactions catalysed by omegaamidase preparations. J. BioI. Chem. 215: 441-460.

Melenders AV, Unno H, Shiragami N, Honda H. 1992. A critical concept of critical velocity for cell disruption by Bead mill. J. Chem. Japan 25:354-357.

Menon J, Mathews L, Purushothaman KK. 2008. Treating Leukemia in a Resource poor setting. Ind. Pediatr. 45:410-412.

Mesas JM, Gill JA and Martin JF (1990) Characterization and partial purification of L-asparaginase from Corynebacterium glutamicum. J. Gen. Microbiol. 136: 515-519.

Mohapatra BR, Sani RK and Banerjee UC. 1995. Characterization of Lasparaginase from Bacillus sp. isolated from an intertidal marine alga Sargassum sp. Lett. Appl. Microbiol. 21:380-383.

Oettgen HF, Old LJ, Boyae EA, Campbell HA, Philips FS,Clarkson, BD, Tallal L, Leper RD, Schwartz MK, Kim JH. 1967. Inhibition of leukemias in man by L-asparaginase. Cancer Res. 27: 26192631.

Prakasham RS, Hymavathi M, Ch Subba Rao, Arepalli SK, Rao JV, Kavin Kennady P, Nasaruddin K, Vijayakumar JB and Sarma PN. 2009. Evaluation of Antineoplastic Activity of Extracellular Asparaginase Produced by Isolated Bacillus circulans. Appl. Biochem. 
Biotechnol.160(1):72-80.

Pritsa A, Kyriakidis DA. 2001. Lasparaginase of Thermus thermophilus: purification, properties and identification of essential amino acids for its catalytic activity. Mol. Cell. Biochem. 216:93-101.

Raha SK, Rog SK, Dey SK, Chakrabarti SL. 1990. Purification and properties of Lasparaginase from Cylindrocarpon obtusisporum MB-10. J. Biochem. 21:987-1000.

Rozalska M, Mikucki J. 1992. Staphylococcal L-asparaginase; catabolic repression of synthesis. Acta. Microbiol. Pol. 41:145150

Sanches M, Krauchenco S, Polikarpov I. 2007. Structure, substrate complexation and reaction mechanism of bacterial asparaginase. Chem. Bio. 1:75-86.

Schnebli HP and Abrams A. 1970. Membrane adenosine triphosphate from Streptococcus feacalis. J. Biol. Chem. 245:1115-1121.

Schutte H and Kula MR. 1993. Cell disruption and isolation of non-secreted products. In: H.J. Rehm and G. reed (Eds). Biotechenol. 3:505-526.

Singh RS. 2013. A comparative study on cell disruption methods for release of aspartase from E. coli K-12. Indian J. Exp. Biol. 51:997-1003.
Sokolov NN, Zanin VA and Aleksandrova SSV. 2000. Three-dimensional structure of Erwinia carotovora L-asparaginase. Med. Khim. 46:6.

Somerville HJ, Delafield FR and Rittenberg SC. 1970. Uera_mercaptoethanolsoluble protein from spores of Bacillus thuringiensis and other spieces. J. Bacteriol. 101:551-560.

Stecher AL, Morgantetti P, Polikarpov I, Abrahao-Neto J. 1999. Stability of Lasparaginase: an enzyme used in leukemia treatment. Pharmaceutia. Acta. Helvetiae. 74: 1-9.

Swain AI, Jaskolski M, Housset D, Mohana Rao JK, Wlodawer A. 1993. Crystal structure of Escherichia coli Lasparaginase an enzyme used in cancer therapy. Proc. Natl. Acad. Sci. USA.90: 1474-1478.

Umesh K, Shamsher S, Wamik A. 2007. Pharmacological and clinical evaluation of L-asparaginase in the treatment of Leukemia. Crit. Rev. Oncol. Hematol. 61: 208-221.

Wang B, Relling MV, Storm MC. 2003. Evaluation of immunologic cross reaction of antiasparaginase antibodies in acute lymphoblastic leukemia (ALL) and lymphoma patients. Leukemia 17:1583-1588.

\section{How to cite this article:}

Manisha Gautam, Nisha and Wamik Azmi. 2020. Optimization of Extraction Techniques for the Release of Intracellular L-Asparginase from Serratia Marcescens MTCC 97 and its Characterization. Int.J.Curr.Microbiol.App.Sci. 9(03): 260-287. doi: https://doi.org/10.20546/ijcmas.2020.903.032 